\title{
High-frequency monitoring reveals nutrient sources and transport processes in an agriculture-dominated lowland water system
}

\author{
Bas van der Grift ${ }^{1,2}$, Hans Peter Broers ${ }^{3}$, Wilbert Berendrecht ${ }^{4}$, Joachim Rozemeijer ${ }^{2}$, Leonard Osté ${ }^{2}$, and \\ Jasper Griffioen ${ }^{1,3}$ \\ ${ }^{1}$ Copernicus Institute of Sustainable Development - Faculty of Geosciences, Utrecht University, P.O. Box 80115, \\ 3508 TA Utrecht, the Netherlands \\ ${ }^{2}$ Deltares, P.O. Box 85467, 3508 AL Utrecht, the Netherlands \\ ${ }^{3}$ TNO Geological Survey of the Netherlands, P.O. Box 80015, 3508 TA Utrecht, the Netherlands \\ ${ }^{4}$ Berendrecht Consultancy, Stakenbergerhout 107, 3845 JE Harderwijk, the Netherlands \\ Correspondence to: Bas van der Grift (bas.vandergrift@deltares.nl)
}

Received: 9 June 2015 - Published in Hydrol. Earth Syst. Sci. Discuss.: 25 August 2015

Revised: 25 March 2016 - Accepted: 21 April 2016 - Published: 11 May 2016

\begin{abstract}
Many agriculture-dominated lowland water systems worldwide suffer from eutrophication caused by high nutrient loads. Insight in the hydrochemical functioning of embanked polder catchments is highly relevant for improving the water quality in such areas or for reducing export loads to downstream water bodies. This paper introduces new insights in nutrient sources and transport processes in a polder in the Netherlands situated below sea level using high-frequency monitoring technology at the outlet, where the water is pumped into a higher situated lake, combined with a low-frequency water quality monitoring programme at six locations within the drainage area. Seasonal trends and short-scale temporal dynamics in concentrations indicated that the $\mathrm{NO}_{3}$ concentration at the pumping station originated from $\mathrm{N}$ loss from agricultural lands. The $\mathrm{NO}_{3}$ loads appear as losses via tube drains after intensive rainfall events during the winter months due to preferential flow through the cracked clay soil. Transfer function-noise modelling of hourly $\mathrm{NO}_{3}$ concentrations reveals that a large part of the dynamics in $\mathrm{NO}_{3}$ concentrations during the winter months can be related to rainfall. The total phosphorus (TP) concentration and turbidity almost doubled during operation of the pumping station, which points to resuspension of particulate $P$ from channel bed sediments induced by changes in water flow due to pumping. Rainfall events that caused peaks in $\mathrm{NO}_{3}$ concentrations did not results in TP concentration peaks. The rainfall induced and $\mathrm{NO}_{3}$ enriched quick interflow, may also be enriched in TP but retention of TP due to sedimentation of
\end{abstract}

particulate $\mathrm{P}$ then results in the absence of rainfall induced TP concentration peaks. Increased TP concentrations associated with run-off events is only observed during a rainfall event at the end of a freeze-thaw cycle. All these observations suggest that the $\mathrm{P}$ retention potential of polder water systems is primarily due to the artificial pumping regime that buffers high flows. As the TP concentration is affected by operation of the pumping station, timing of sampling relative to the operating hours of the pumping station should be accounted for when calculating P export loads, determining trends in water quality, or when judging water quality status of polder water systems.

\section{Introduction}

Many surface water bodies suffer from eutrophication caused by high nutrient loads. Eutrophication of surface waters can lead to turbid waters with decreased oxygen levels (hypoxia), toxin production by algae and bacteria, and fish kills (Bouwman et al., 2013a). Policy makers of national governments, the European Union and other authorities aim to improve water quality in surface water bodies that receive nutrient load from agriculture or other sources like sewage effluent (EC, 2000). A sound assessment of pressures and impacts on the aquatic ecosystem and a reliable assessment of water status in catchments is, therefore, a topic of major importance. If the assessment of pressures is flawed, the action plans will 
be ill founded and there is a risk that EU member states will not carry out their work where it is most needed and in a cost-effective way (EC, 2015). This holds strongly for the Netherlands where nutrient surpluses and leaching are higher than elsewhere in Europe (van Grinsven et al., 2012) and the world (Bouwman et al., 2013b), due to a highly concentrated and productive agricultural sector.

For the evaluation of action programmes and pilot studies, water authorities invest heavily in the monitoring of $\mathrm{NO}_{3}$ and $\mathrm{P}$ concentrations in surface water. Regional surface water quality networks in EU member states are commonly sampled 12 times a year (Fraters et al., 2005). However, the interpretation of grab sample data in terms of loads and fluxes is often problematic from such monitoring networks (Rozemeijer et al., 2010). Grab sample frequencies are generally not sufficient to capture the dynamical behaviour of surface water quality and hydrological functioning of the catchment (Kirchner et al., 2004; Johnes, 2007). It is increasingly recognised that incidental losses and peak flows play an important role in the nutrient loads of surface water systems in the Netherlands (Van der Salm et al., 2012; Regelink et al., 2013) and elsewhere (Withers et al., 2003). Such incidental losses are considered to be related to peak flows after heavy rain storms and due to overland flow or quick interflow via drains and cracked clay soils and related leaching of manure and erosion of soil particles (Kaufmann et al., 2014). Some authors observed a lowering of $\mathrm{NO}_{3}$ concentrations shortly after peak flow (e.g. Poor and McDonnell, 2007; Shrestha et al., 2013) caused by dilution with $\mathrm{NO}_{3}$-poor precipitation water. Others detected concentration peaks in response events (e.g. Rozemeijer and Broers, 2007; Tiemeyer et al., 2008). Therefore, the $\mathrm{NO}_{3}$ response to rainfall events depends on the hydrochemical properties of the catchment (Rozemeijer et al., 2010). In addition, the capacity of surface water bodies to retain nutrients is spatially and temporally variable (e.g. Withers and Jarvie, 2008; Cirmo and McDonnell, 1997).

As a consequence of the dynamic behaviour of nutrient transfer from land to surface water and in-stream processes that impact nutrient retention combined with increasing demands for sound assessments of the water system, there is an increasing interest in continuous or semi-continuous monitoring of water quality at catchment outlets during the last decade (e.g. Bowes et al., 2015; Wade et al., 2012; Jordan et al., 2007; Bieroza et al., 2014; Palmer-Felgate et al., 2008; Rozemeijer et al., 2010; Kirchner et al., 2004; Cassidy and Jordan, 2011; Skeffington et al., 2015). These studies showed catchment-dependent non-stationary behaviour of the concentration-discharge relationships. High-frequency monitoring has proven to be a powerful tool to improve estimations of annual export loads (e.g. Rozemeijer et al., 2010; Cassidy and Jordan, 2011), nutrients sources (Bowes et al., 2015) and the hydrochemical functioning of a catchment (e.g. Wade et al., 2012; Bieroza et al., 2014; Halliday et al., 2012). High-frequency nutrient monitoring has revealed the presence of diurnal nutrient cycles in rivers and streams caused by biological processes or by $\mathrm{P}$ and $\mathrm{N}$ inputs from sewage treatment works (e.g. Bowes et al., 2015; Halliday et al., 2012; Neal et al., 2012). Large changes in concentrations or fluxes of materials over relatively short time periods are increasingly recognised as important pathways of nutrient delivery to surface water bodies (Kaushal et al., 2014). In the Netherlands, there is a still debate about the risk of incidental losses associated with manure application (Akkermans and Hermans, 2014). The Netherlands adopted the European Nitrate Directive in 1991 (EC, 1991), which regulates the use of nitrogen in agriculture through national action plans. Among other measures, the regulation includes the period of manure application. To reduce the risk of nutrient leaching to groundwater and surface water, manure application on arable land is allowed from 1 February to 1 August and on grassland from 15 February to 31 August (LNV, 2009). The potential risk for incidental nutrient losses after manure application in February and March (before the start of the growing season) is not known. High-frequency monitoring is a powerful tool to detect such incidental losses.

In many low-lying areas worldwide, water levels are managed by inlet of diverted river water in dry periods and discharge via pumping stations in wet periods. Such an embanked land with a human controlled water regime is called a "polder". In the Netherlands, these regulated polder catchments cover $60 \%$ of the land surface (Van de Ven, 2004). The dense network of subsurface drains, ditches, weirs, channels, pumping stations, and the dynamic mixing of water from different sources (seepage, precipitation, and water inlet) results in a relatively complex hydrology. Many studies on nutrient dynamics in natural catchments showed a relation between nutrient concentrations and discharge, and this significantly improved the insight in the nutrient sources and pathways in the catchment. The water flow in polders is, however, not a function of free discharge but is controlled by pumping stations. The maximum discharge is controlled by the capacity of the pumping stations. Due to the presence of a dense surface water system, the water storage capacity and the residence time of the surface water in a polder is also higher when compared to natural, free drainage catchments, which may impact biogeochemical or hydrological in-stream processes controlling nutrient retention. Insight in the hydrochemical functioning of polder catchments is highly relevant for improving the water quality in the Netherlands.

To our knowledge, high-frequency monitoring of surface water quality has not been applied for polder catchments up to now. Discharge-concentration relationships and shortscale variation in water quality in polder catchments are still unclear while nutrient sources and pathways are poorly understood (Rozemeijer et al., 2014). High-frequency measurements reveal the short-term variability in solute concentrations, which may give valuable insight into the contribution of different sources or different flow routes to the surface water pollution in polders. 
The general aim of this study is to increase our understanding of the hydrochemical function of an agriculturedominated water system in a clay polder by analysis of highfrequency monitoring of nutrient concentrations at the polder outlet combined with low-frequency surface water quality data and groundwater quality data from different locations within the polder. The specific objectives of this study are (1) to increase insight in dynamics of nutrient concentrations and nutrient sources in polder areas (2) to characterise the importance of incidental losses caused by intensive rainfall events whether or not in combination with recent manure application, and (3) to assess potential effects of the operational management of the pumping station on the water quality.

\section{Material and methods}

\subsection{Study area}

A continuous monitoring station was established in the Lage Vaart main channel nearby the pumping station Blocq van Kuffeler (A in Fig. 1). This is one of the three pumping stations that control the water level in Lage Afdeling pumped drainage area located within the Flevoland polder, the most recent and at the same time biggest land reclamation project in the Netherlands (Groen, 1997). The Flevoland polder consists of two pumped drainage areas, which are each drained by a main channel. The Lage Afdeling drainage area drains into the Lage Vaart main channel (Fig. 1). The size of the Lage Afdeling drainage area is $576 \mathrm{~km}^{2}$, with altitude ranging between 3 and $5 \mathrm{~m}$ b.m.s.l. (below mean sea level). The Lage Afdeling drainage area is mainly rural. The land cover is dominated by agriculture ( $76 \%$ ), followed by woodlands and moors $(18 \%)$ and urban or semi-urban areas $(6 \%)$.

The geohydrology of the Flevoland polder area is generally described by a confining layer of Holocene marine sediments, with a thickness of less than $0.5 \mathrm{~m}$ in the northeast to over $7 \mathrm{~m}$ southwest, overlying a sandy aquifer deposited in the Pleistocene age. The soils consist for $50 \%$ of clay soils, for $39 \%$ of silty clay loam and for $11 \%$ of sandy soils (Van den Eertwegh, 2002). A typical characteristic of the soils in Flevoland is that the clay layer contains permanent and interconnected cracks due to physical and chemical ripening of the soil after reclamation. The shrinkage cracks disappeared in the plough layer by tillage activities, but are permanently present in the subsoil down to about $1.0-1.5 \mathrm{~m}$ below the soil surface (Van den Eertwegh, 2002; Groen, 1997). From a depth of 1.2 to $1.5 \mathrm{~m}$ below the soil surface, clay deposits, if present, are permanently water saturated and thus not ripened, resulting in a low-permeable soil layer. Due to altitudes below mean sea level and below the water level of the surrounding lakes, there is upward groundwater seepage at most locations within the Lage Afdeling drainage area.

The Lage Vaart main channel is connected via a series of secondary channels to a dense network of field ditches

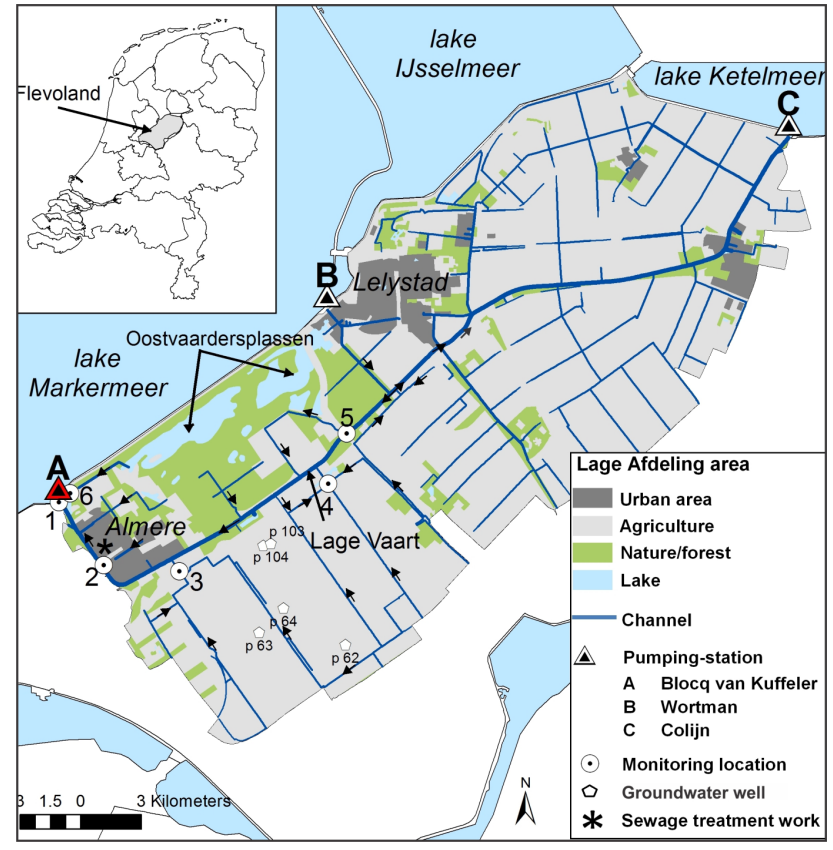

Figure 1. Map of the Lage Afdeling pumped drainage area, the continuous monitoring station at location A, the low-frequency surface water monitoring locations, and the groundwater level monitoring wells. The flow direction of the water in the channels that are drained by pumping station Blocq van Kuffeler is illustrated by arrows.

and tube drains. Tube drains are generally installed at $0.95 \mathrm{~m}$ depth. The horizontal spacing varies between less than 12 to $48 \mathrm{~m}$, mainly dependent on the soil hydraulic conductivity and groundwater seepage rate. The field ditches receive outflow from the tube drain, direct drainage from subsurface flow, regional groundwater seepage, and any surface runoff from the connected field area. They drain freely into the secondary channels. The water level in the Lage Afdeling is regulated by 97 weirs and three pumping stations that pump the excess water to the higher situated Markermeer and Ketelmeer. The total pumping capacity is $11-12 \mathrm{~mm} \mathrm{day}^{-1}$. The Lage Vaart main channel has a controlled constant water level of $6.2 \mathrm{~m}$ b.m.s.l. The pumping station Blocq van Kuffeler has four electrically powered pumps. Two pumps with a capacity of $750 \mathrm{~m}^{3} \mathrm{~min}^{-1}$ each drain the Lage Afdeling. Operation of the pumping stations with one pump causes a flow velocity in the main channel of approximately $0.125 \mathrm{~m} \mathrm{~s}^{-1}$ and with both pumps the flow velocity is approximately $0.25 \mathrm{~m} \mathrm{~s}^{-1}$. Up to 2008, the pumping station Blocq van Kuffeler was powered with diesel engines. These diesel engines were replaced with electric engines during the renovation of the pumping station in the autumn of 2008 and this conversion was finished in the beginning of 2009. Since this renovation, the operational management of the pumping station is automatically controlled by a series of water level pressure sensors in the area. The pumps run predominantly dur- 
Table 1. Locations of the low-frequency monitoring programme in Lage Afdeling pumped drainage area that is drained by the Blocq van Kuffeler pumping station.

\begin{tabular}{ll}
\hline Location & Description \\
\hline 1 & Lage Vaart main-channel at pumping station "Blocq van Kuffeler"; outlet of the Lage Afdeling drainage area \\
2 & Outlet of sub-channel that drains the urban area of the city "Almere" \\
3 & Outlet of sub-channel that drains the agricultural "Gruttotocht" \\
4 & Outlet of sub-channel that drains the agricultural "Lepelaartocht" \\
5 & Far end of Lage Vaart main channel that is drained by the pumping station "Blocq van Kuffeler" \\
6 & Outlet of channel that drains the nature area "Oostvaardersplassen" \\
\hline
\end{tabular}

ing evening or night hours because of cheaper power supply during these hours. The discharge generated by the pumping stations is measured continuously. The Blocq van Kuffeler pumping station drains the south-western part of the Lage Afdeling drainage area. The flow direction of the water in the channels, which are drained by pumping station Blocq van Kuffeler, is illustrated by arrows in Fig. 1. Pumping station B is an emergency pumping station and only operates during extremely wet conditions. Although there is no physical boundary between the area drained by Blocq van Kuffeler and pumping station C, location 5 can be considered as the most upstream location in the Lage Vaart that is drained by the Blocq van Kuffeler pumping station under normal meteorological conditions. There is a Wastewater Treatment Plant (WWTP) in the area that discharges its effluent to the Lage Vaart (Fig. 1). The average effluent discharge is $0.35 \mathrm{~m}^{3} \mathrm{~min}^{-1}$. The total phosphorus (TP) and $\mathrm{NO}_{3}$ concentration in the effluent water is measured weakly. The average TP concentration is $0.5 \mathrm{mg} \mathrm{L}^{-1}$ and the average $\mathrm{NO}_{3}$ concentration is $1.5 \mathrm{mg} \mathrm{N} \mathrm{L}^{-1}$. The TP load to the Lage Vaart in the period October 2014-October 2015 equals approximately $5400 \mathrm{~kg}$ and the $\mathrm{NO}_{3}$ load $16400 \mathrm{~kg} \mathrm{~N}$. There are no other sources of sewage discharge to the surface water within the Lage Afdeling drainage area.

\subsection{Low-frequency monitoring}

Grab samples were collected every 2 or 4 weeks from January 2014 to October 2015 from the polder outlet and five other monitoring locations within the part of the Lage Afdeling drainage area that is drained by the Blocq van Kuffeler pumping station (Fig. 1). Four locations are representative for different types of land use (Table 1). Electrical conductivity, oxygen concentration, transparency, temperature and $\mathrm{pH}$ of the samples were measured directly in the field. Subsamples for determination of dissolved substances were filtered through a $0.45 \mu \mathrm{m}$ pore size filter (Eijkelkamp). The samples were transported and stored at $4{ }^{\circ} \mathrm{C}$. TP, dissolved reactive $\mathrm{P}$ (DRP), $\mathrm{NO}_{3}, \mathrm{NH}_{4}$, and $\mathrm{Cl}$ were determined using standard colorimetric methods (APHA-AWWA-WPCF, 1989). Organic N was extracted by Kjeldahl extraction and measured by colorimetric method and sulfate was measured using IC (Ion Chromatography).
The water quality in the Lage Afdeling drainage area showed spatial differences in water quality related to land use (Fig. S1 in the Supplement). High $\mathrm{NO}_{3}$ concentrations were observed in water from the agricultural during winter (location 3 and 4 in Fig. 1). The highest TP concentrations were observed in water from the nature area Oostvaardersplassen (location 6 in Fig. 1). The DRP concentration of all sampling locations showed a seasonal variation with higher concentrations during the summer months.

\subsection{High-frequency measurements}

Between October 2014 and October 2015 we measured the TP, total reactive $\mathrm{P}$ (TRP) and $\mathrm{NO}_{3}$ concentration, turbidity, conductivity, and water temperature semi-continuously at the polder outlet just before the pumping station. TRP include all $\mathrm{P}$ forms that are measured with the molybdenum blue method (Murphy and Riley, 1962) in unfiltered samples, those include acid labile phosphorus containing compounds (inorganic and organic) (Worsfold et al., 2005). The flow regime at the monitoring location is governed almost exclusively by the pumping station. The conductivity was measured continuously with a conductivity, temperature and depth (CTD) sensor (CTD-diver, Van Essen Instruments, Delft, the Netherlands).

The $\mathrm{NO}_{3}$ concentration was measured using a double wavelength spectrophotometric sensor (DWS), (Nitratax plus sc, Hach Lange GmbH, Düsseldorf, Germany). The DWS measures UV absorbance of dissolved $\mathrm{NO}_{3}$ at a wavelength of $218 \mathrm{~nm}$ at a measuring receiver (EM - element for measuring) and at $228 \mathrm{~nm}$ at a reference receiver (ER - element for reference). The recorded measurements at two different wavelengths are designed to compensate interference of organic and/or suspended matter by interpreting the difference between the absorbance values at EM and ER (Huebsch et al., 2015). The Nitratax sensor covers a $\mathrm{NO}_{x}-\mathrm{N}$ detection range of 0.1 to $50.0 \mathrm{mg} \mathrm{L}^{-1}$. The $\mathrm{NO}_{3}$ concentrations were recorded every $5 \mathrm{~min}$. There was a small drift in the signal of the Nitratax sensor ( $\max 0.35 \mathrm{mg} \mathrm{N} \mathrm{L}^{-1}$ per month). We, therefore, corrected the high-frequency $\mathrm{NO}_{3}$ data using the $\mathrm{NO}_{3}$ concentrations from the bi-weekly grab samples by calculating a linear drift for the separate maintenance intervals of the sensor. 
For the TP concentration measurements, we installed a Sigmatax sampler and a Phosphax Sigma auto-analyser (both Hach Lange GmbH, Düsseldorf, Germany). The total-P concentrations were recorded every $20 \mathrm{~min}$. The Sigmatax was installed for the automated water sample collection and the pretreatment (ultrasonic homogenisation). Next, the sample was delivered to the Phosphax Sigma auto-analyser. This sample was digested using the sulfuric acid-persulfate method (APHA-AWWA-WPCF, 1989). After mixing and quickly heating and cooling down the sample, the reagents were automatically added and the sample was measured at $880 \mathrm{~nm}$ using a LED photometer. The Phosphax Sigma was automatically cleaned and calibrated daily. There was a close agreement between the high-frequency TP data and the TP concentrations of the accompanying two weekly grab samples analysed by standard laboratory assays $\left(R^{2}=0.982\right)$ and, therefore, no need to correct the high-frequency TP data (Fig. S2).

The turbidity (formazin turbidity unit, FTU) was measured using a OBS (optical back scatter) sensor (SOLITAX t-line sc, Hach Lange GmbH Düsseldorf, Germany) that receives the reflected light from the sediment-laden flow. Instead of directly obtaining the suspended sediment concentration, a turbidity sensor measures the turbidity of flow caused by suspended sediment (Gao, 2008). The FTU data were stored with a time interval of $5 \mathrm{~min}$. There was a close agreement between the high-frequency turbidity data (FTU) and the suspended sediment (SS) concentrations $\left(\mathrm{mg} \mathrm{L}^{-1}\right)$ of the grab samples $\left(R^{2}=0.965\right)$ (Fig. S2). The measured turbidity could thus be taken as a proxy for the SS concentration.

\subsection{Background information}

Precipitation data on an hourly basis for the Lage Afdeling were abstracted from HydroNet (http://portal.hydronet.nl/). This is an online database with precipitation data based on calibrated radar images. The precipitation of the radar pixels were averaged over the Lage Afdeling drainage area. Temperature data were retrieved from the Royal Dutch Meteorological Institute (KNMI, De Bilt, the Netherlands) weather station Lelystad, located in the centre of the Lage Afdeling. The Flevoland polder has a moderate maritime climate with an average annual temperature of $9.9^{\circ} \mathrm{C}$, an average annual precipitation of $850 \mathrm{~mm}$ and an average of 8 days per year with a maximum temperature below $0^{\circ} \mathrm{C}$. Groundwater levels were monitored continuously with pressure sensors in five phreatic groundwater wells located within the agricultural area of the Lage Afdeling (Fig. 1).

The groundwater quality data set from Griffioen et al. (2013) was used as background information. This database was assembled from the national database of the TNO Geological Survey of the Netherlands and contains complete groundwater analyses down to a depth of about $30 \mathrm{~m}$ with sampling dates later than 1945 . The groundwater in the Lage Afdeling is characterised as anoxic fresh to saline $\left(\mathrm{Cl}\right.$ between 7 and $\left.4500 \mathrm{mg} \mathrm{L}^{-1}\right)$ and $\mathrm{P}$ rich (TP between 0.01 and $3.6 \mathrm{mg} \mathrm{P} \mathrm{L}^{-1}$ ) with low $\mathrm{NO}_{3}$ concentrations (between 0 and $7 \mathrm{mg} \mathrm{NO}_{3} \mathrm{~L}^{-1}$ ) (Fig. S3).

\subsection{Transfer function-noise modelling}

To increase insight in the driving forces of measured dynamics of nutrient concentrations, preliminary research was done on the application of time-series analysis, and more specifically transfer function-noise (TFN) modelling, to estimate the impact of rainfall on $\mathrm{NO}_{3}$ concentrations. TFN models are very popular for describing dynamic causal relationships between time series and have been widely applied in the field of groundwater modelling (e.g. Berendrecht et al., 2003; Knotters and van Walsum, 1997). Although a small number of studies have used TFN models to relate streamflow data to nutrient concentrations (Schoch et al., 2009; Worrall et al., 2003) or relate precipitation data to high-frequency observation of dissolved organic carbon (Jones et al., 2014), to our knowledge TFN models have not been applied yet on highfrequency monitoring data of nutrients such as those available in this study. Therefore, as a first step, we tried to relate the time series of hourly $\mathrm{NO}_{3}$ concentration measurements to rainfall using the following linear TFN model:

$\log \left(\mathrm{NO}_{3}\right)=\theta(B) p_{t}+\mu+n_{t}$

and

$n_{t}=\phi n_{t-1}+\varepsilon_{t}$,

where $p_{t}$ is the precipitation at time $t, \theta(B)=\theta_{0}+\theta_{1} B+$ $\ldots+\theta_{r} B^{r}$ the transfer function ( $B$ is backward shift operator, $\left.B^{i} p_{t}=p_{t-i}\right), \mu$ the reference or baseline level, $n_{t}$ a stochastic first-order autoregressive process, $\phi$ the autoregressive coefficient $(0<\phi<1)$, and $\varepsilon_{t}$ a zero-mean normally distributed process (Box and Jenkins, 1970). As $\varepsilon_{t}$ is assumed to be normally distributed, the time series of $\mathrm{NO}_{3}$ data was log-transformed to better satisfy this assumption. For reasons of flexibility and model parsimony, we used a predefined transfer function as described by von Asmuth et al. (2002), which has the form of a Gamma distribution function and has been successfully applied for describing groundwater dynamics:

$\theta_{t}=A^{*} t^{n-1} e^{-a t}, A^{*}=A \frac{a^{n}}{\Gamma}(n)$,

where the parameters $A^{*}, a, n$, and the stochastic model parameter $\alpha$ are estimated using a log-likelihood function, and $\Gamma(n)$ is the gamma function.

\subsection{Export load calculations and trend analysis}

True $\mathrm{NO}_{3}$ and TP export loads from the drainage area into the Markermeer were based on our high-frequency concentration measurements and discharge data of the pumping sta- 

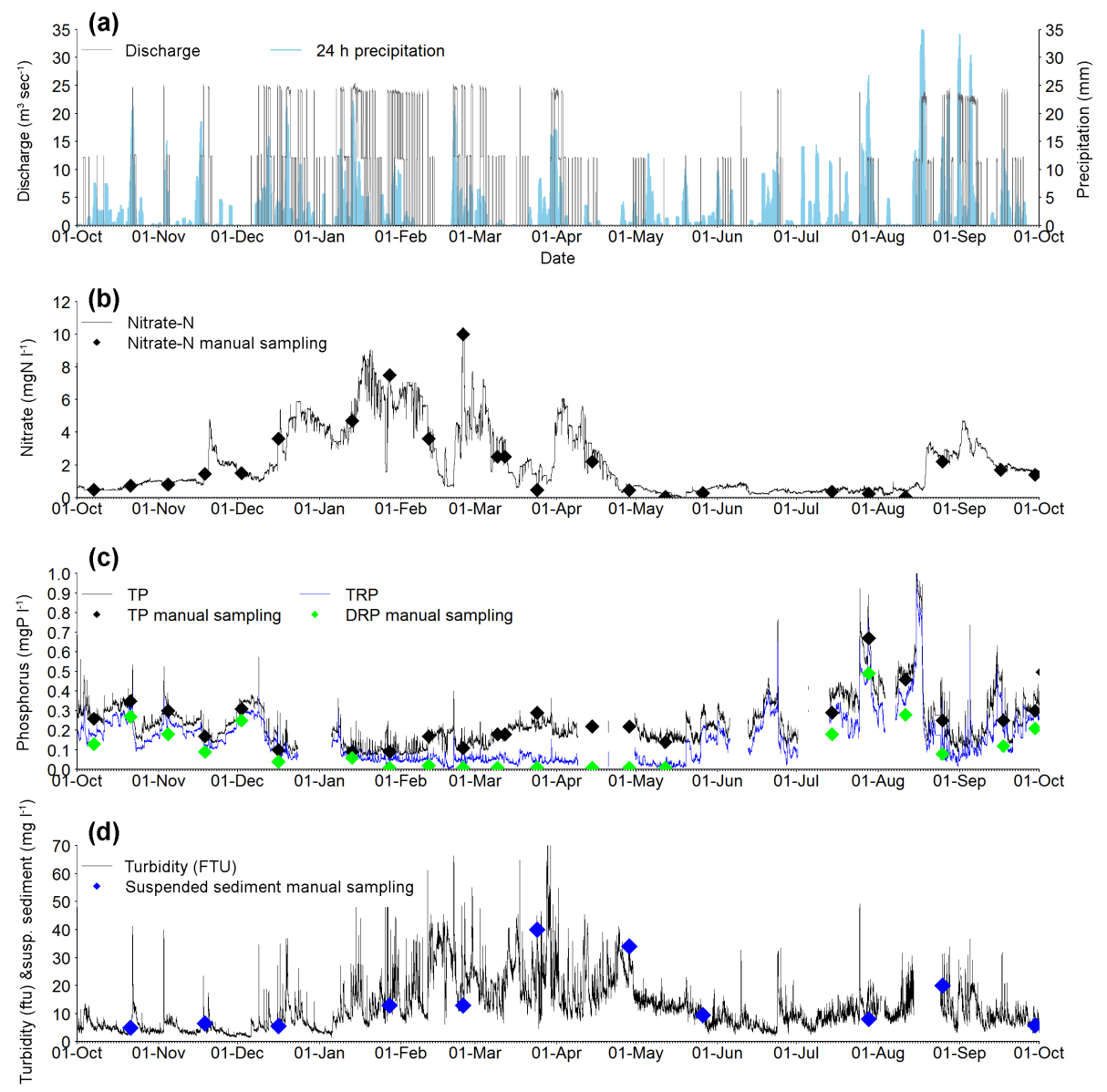

Figure 2. TP, $\mathrm{NO}_{3}$, and $\mathrm{SS}$ export loads and discharge at the pumping station Blocq van Kuffeler. The measured load is calculated from the high-frequency data, the grab sample load is calculated from interpolation of the low-frequency data, the TP baseline load was calculated with the high-frequency TP data after separation of the short-scale concentration peaks generated by the pumping station.

tion. In addition $\mathrm{NO}_{3}$ and $\mathrm{TP}$ loads were estimated from linear interpolation of the low-frequency grab sample data combined with the discharge data. Although advanced methods have been developed to improve load estimates from lowfrequency concentration data, none of the methods clearly outperformed the methods that were based on simple linear or stepwise interpolation (Rozemeijer et al., 2010). To quantify the event-driven TP export load generated by changes in the water flow due to pumping, a hydrograph separation method was used to separate the high-frequency TP concentration data series into short-term TP concentration peaks and baseline TP concentration. In this study we used the same method as applied by Rozemeijer and Broers (2007). This method, originally developed by Hewlett and Hibbert (1963), separates the baseline concentration and the peak concentration by a separation line with a constant slope (Fig. S5). This line starts whenever the slope of the concentration series exceeds a specified constant separation slope. The separation line ends when it intersects the falling limb of the concentration series. For this study, a constant separation slope of $0.02 \mathrm{mg} \mathrm{PL}^{-1}$ day $^{-1}$ was used. With this relatively low slope value, concentration peaks were also separated from the baseline concentration during situations of upward trends in TP concentrations.

Long-term $\mathrm{TP}$ and $\mathrm{NO}_{3}$ concentration measurements were available for the polder outlet. We used two frequently applied methods for trend analysis of concentration-time series: (1) seasonal Mann-Kendall tests (Hirsch and Slack, 1984), (2) Theil-Sen robust line (Hirsch et al., 1982), and (3) locally weighted scatter plot smoothing (LOWESS) trend lines (Cleveland, 1979). These methods are relatively insensitive to extreme values and missing data in the time series. The seasonal Mann-Kendall trend test is a robust, non-parametric test on the significance of an upward or downward trend. The Theil-Sen method is a robust non-parametric trend slope estimator. The LOWESS trend lines were used to examine possible changes in trend slopes within the concentration-timeseries period. We refer to Rozemeijer et al. (2014) for details on the statistical methods. 


\section{Results}

\subsection{Water discharge}

The Blocq van Kuffeler pumping station responds rapidly to rainfall events in the drainage area by automatically switching on one or two pumps (Fig. 2a). The interval in which the pumping station is in operation decreased during the autumn months. During the winter months the pumping station runs almost at a daily basis and continuously for several days during very wet periods. There was a strong decline of the daily pumping hours from mid-April to the end of July. A wet period from mid-August to mid-September resulted in an increase of pumping hours. The pumping station pumped almost $67 \times 10^{6} \mathrm{~m}^{3}$ water from the polder into the Markermeer during the period from October 2014 until March 2015 and $33 \times 10^{6} \mathrm{~m}^{3}$ during the period from April 2015 until October 2015 (Fig. 3). This corresponds to approximately $350 \mathrm{~mm}$ distributed across the entire drainage area for the winter halfyear (October-March) and $170 \mathrm{~mm}$ for the summer half-year (April-September). The sum of the precipitation amounted to 455 and $517 \mathrm{~mm}$ for the winter half-year and summer halfyear, respectively.

\subsection{Seasonal trends in high-frequency nutrient data}

The high-frequency $\mathrm{NO}_{3}$ concentration ranged from 0.01 to $10.4 \mathrm{mg} \mathrm{N} \mathrm{L}^{-1}$ and showed a seasonal pattern and a response to rainfall with high concentrations in winter and an increase during wet periods (Fig. 2b). The $\mathrm{NO}_{3}$ concentration was low from the start of the monitoring until half November. From mid-November to the third week of January, the $\mathrm{NO}_{3}$ concentration gradually increased to a maximum of $9 \mathrm{mg} \mathrm{N} \mathrm{L}^{-1}$. During the dry period in the first 3 weeks of February, the $\mathrm{NO}_{3}$ concentration decreased to a level of $1 \mathrm{mg} \mathrm{N} \mathrm{L}^{-1}$. Next, the concentration peaked at 24-25 February upon rainfall and gradually decreased towards the end of March where it showed an increase again during the wet period in late March and early April. During April the concentration declined to a level around $0.5 \mathrm{mg} \mathrm{NL}^{-1}$ or below and stayed at this low level until mid-August. The $\mathrm{NO}_{3}$ concentration rapidly increased after a wet period during mid-August and gradually decreased afterward.

The high-frequency TP concentration ranged from 0.07 to $1.16 \mathrm{mg} \mathrm{PL}^{-1}$ (Fig. 2c). The TP concentration was relatively high during the first 3 weeks of the monitoring period ( 0.25 to $0.4 \mathrm{mg} \mathrm{PL}^{-1}$ ). In October and November, the TP concentration decreased during wet periods and increased during the dryer periods. During the wet first 2 weeks of December, the TP concentration decreased to a level around $0.1 \mathrm{mg} \mathrm{PL}^{-1}$ and remained low until halfway through February. During the relatively dry period in February and March the TP concentration increased to a level around $0.2 \mathrm{mg} \mathrm{PL}^{-1}$ and remained at this level until mid-June. From mid-June to midAugust the TP concentration gradually increased and peaked in mid-August. With higher concentrations during the summer season and a decrease during wet periods, the TP concentration showed a seasonal variation and a response to rainfall that was opposite to the $\mathrm{NO}_{3}$ concentration.

The high-frequency total-reactive P (TRP) data and the dissolved-reactive $\mathrm{P}$ (DRP) data from the low-frequency monitoring programme showed rather high concentrations from the start of the monitoring to early December 2014 and then declined to a low level (Fig. 2c). The TRP and DRP concentration remained low until the second half of May. During the period from mid-May to mid-August the TRP and DRP concentrations followed the trend of the increasing TP concentrations.

The baseline level of the SS concentration was low during the period October to January (Fig. 2d). In January the SS concentration increase and it stayed at a relative high lever to April. During the end of April and May the SS concentration decreased again.

\subsection{Short-scale dynamics in high-frequency nutrient data}

Significant increases of the $\mathrm{NO}_{3}$ concentration up to $8 \mathrm{mg} \mathrm{NL}^{-1}$ in short timescales appeared during pumping within 5 days after major rainfall events on 15-18 November, 10-12 December, 19-20 December, 7-9 January, 12-14 January, 21-22 February, 29 March-2 April, 14-18 August, and 26-31 August (Fig. 4 and Table 2). The precipitation during these events was around $20 \mathrm{~mm}$ or above. After these $\mathrm{NO}_{3}$ concentration peaks, the concentration declined during pumping. The increase in $\mathrm{NO}_{3}$ concentration did not appear after the precipitation events on 20-23 October, 3-4 November, 17-23 June, and 27-29 July.

There is a structural response of the TP concentration and the turbidity on operation of the pumping station. The TP concentration and turbidity always peaked directly after the start of the pumping engines and decreased again during the period of pumping and afterwards (Fig. 4). Pumping events with one pump resulted in an average increase of the TP concentration of $0.06 \mathrm{mg} \mathrm{L}^{-1}$ and turbidity of 4.4 FTU while events with two pumps resulted in an average increase of $0.13 \mathrm{mg} \mathrm{L}^{-1}$ and turbidity of $22 \mathrm{FTU}$ (Table 3 ). The TP concentration was on average a factor of 1.30 and 1.83 higher during pumping with one pump and two pumps, respectively, compared to the concentration before pumping. The TRP concentrations also showed an increase in concentration during pumping. As the colorimetric measurement of TRP takes place in an acidic solution, it is plausible to attribute the increase of the TRP concentration during pumping to the dissolution of particulate $\mathrm{Fe}$ or $\mathrm{Ca}$ bound inorganic $\mathrm{P}$. The data show the largest increase of TP concentrations $(0.16$ $0.60 \mathrm{mg} \mathrm{P} \mathrm{L}^{-1}$ ) during pumping with two pumps after longer periods without pumping (21 October, 2 November, 8 December, 20 February, 23 June, 25 July and 15 August) and decreasing TP peaks were observed with subsequent pump- 

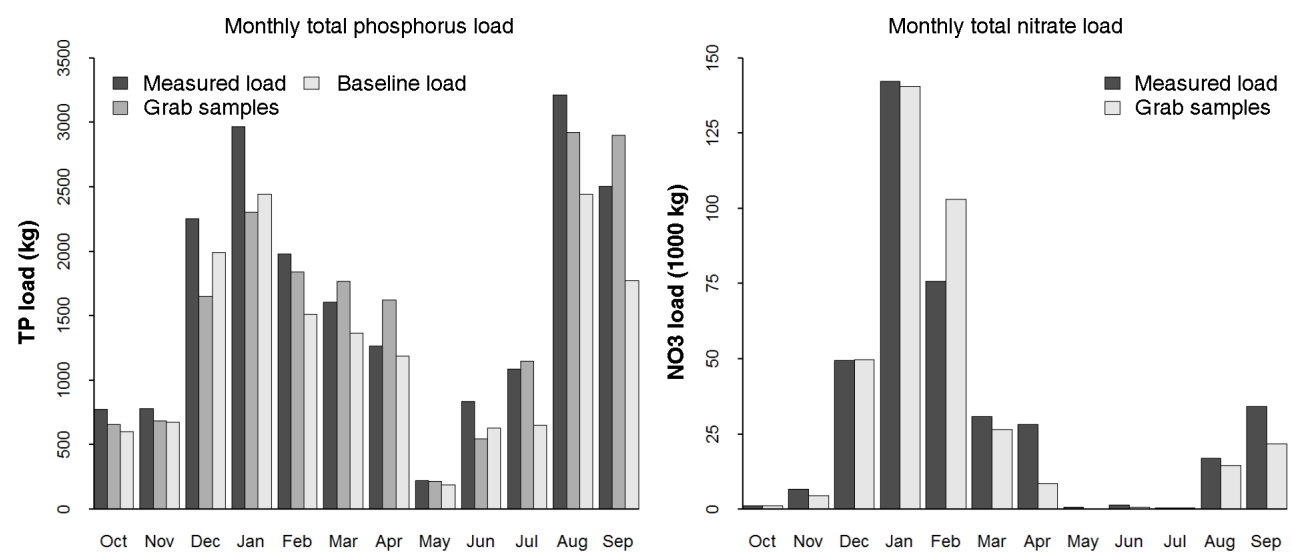

\begin{tabular}{||l|c|c|c||l|c|c|c||}
\hline $\begin{array}{l}\text { Seasonal and annual } \\
\text { load }\end{array}$ & $\begin{array}{c}\text { Winter } \\
\text { (Oct-Mar) }\end{array}$ & $\begin{array}{c}\text { Summer } \\
\text { (Apr-Sep) }\end{array}$ & Year & $\begin{array}{l}\text { Seasonal and annual } \\
\text { load }\end{array}$ & $\begin{array}{c}\text { Winter } \\
\text { (Oct-Mar) }\end{array}$ & $\begin{array}{c}\text { Summer } \\
\text { (Apr-Sep) }\end{array}$ & Year \\
\hline TP $(\mathrm{kg})$ & 10350 & 9150 & 19500 & $\mathrm{NO}_{3}(1000 \mathrm{~kg})$ & 306.3 & 82.3 & 388.6 \\
\hline TP grab samples $(\mathrm{kg})$ & 8900 & 9350 & 18300 & $\begin{array}{l}\mathrm{NO}_{3} \text { grab samples }(1000 \\
\mathrm{kg})\end{array}$ & 326.2 & 46.4 & 372.6 \\
\hline TP baseline $(\mathrm{kg})$ & 8600 & 6900 & 15500 & & & & \\
\hline
\end{tabular}

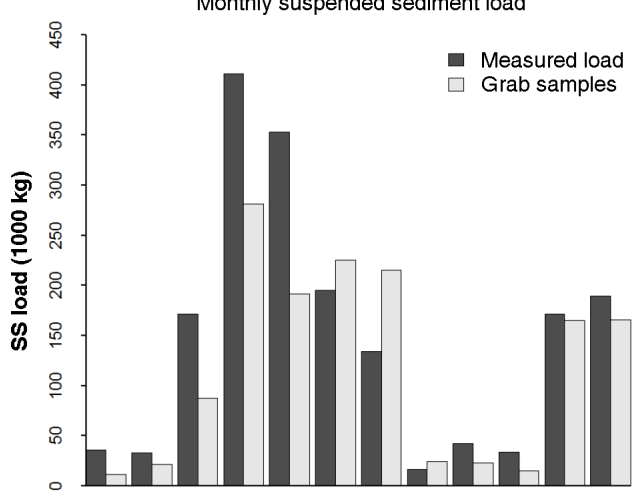

Oct Nov Dec Jan Feb Mar Apr May Jun Jul Aug Sep

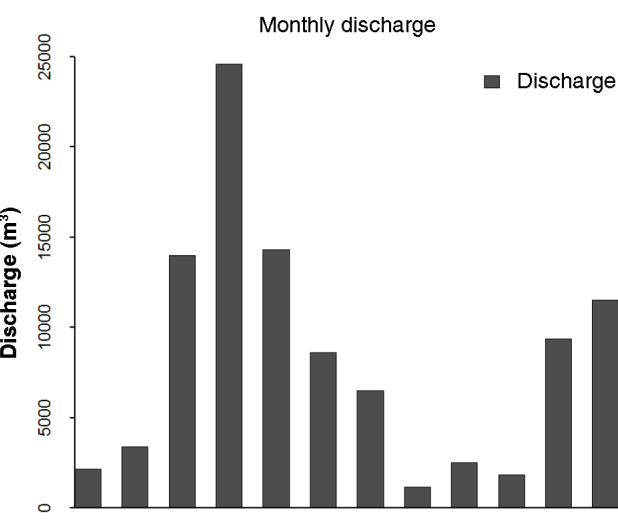

Oct Nov Dec Jan Feb Mar Apr May Jun Jul Aug Sep

\begin{tabular}{|c|c|c|c|c|c|c|c|}
\hline $\begin{array}{l}\text { Seasonal and annual } \\
\text { load }\end{array}$ & $\begin{array}{c}\text { Winter } \\
\text { (Oct-Mar) }\end{array}$ & $\begin{array}{l}\text { Summer } \\
\text { (Apr-Sep) }\end{array}$ & Year & $\begin{array}{l}\text { Seasonal and annual } \\
\text { load }\end{array}$ & $\begin{array}{c}\text { Winter } \\
\text { (Oct-Mar) }\end{array}$ & $\begin{array}{l}\text { Summer } \\
\text { (Apr-Sep) }\end{array}$ & Year \\
\hline SS (1000 kg) & 1200 & 588 & 1788 & Discharge (m3) & 67000 & 33000 & 100000 \\
\hline $\begin{array}{l}\text { SS grab samples (1000 } \\
\mathrm{kg} \text { ) }\end{array}$ & 819 & 609 & 1428 & & & & \\
\hline
\end{tabular}

Figure 3. High-frequency monitoring data for the Lage Vaart channel at the pumping station Blocq van Kuffeler: (a) discharge as generated by the pumping station and 1-day antecedent precipitation; (b) nitrate- $\mathrm{N} 5$ min data, with $\mathrm{NO}_{3}-\mathrm{N}$ manual sampled bi-weekly data; (c) total phosphorus and total reactive phosphorus $20 \mathrm{~min}$ data, with TP and DRP manual sampled bi-weekly data; (d) turbidity 5 min data, with suspended sediment manual sampled monthly data.

ing events (Fig. 4). Short-term declines of the TP concentrations to values below the pre-pumping concentration were observed during pumping or shortly after pumping induced by rainfall periods in October, June and August (Fig. 4).

A significant short-term change in $\mathrm{NO}_{3}$ and $\mathrm{TP}$ concentrations and the conductivity that was not linked to pumping appeared during rainfall on 25 and 26 January (Fig. 4). This period marked the end of a freeze-thaw cycle that started on 20 January. During this period the top soil became frozen. The precipitation during the night of 24 January consisted of snow and this resulted in a snow cover of a few centimetres. Upon rainfall on the frozen soil on 25 January, the $\mathrm{NO}_{3}$ concentration decreased from 6.1 to $1.5 \mathrm{mg} \mathrm{N} \mathrm{L}^{-1}$ and the $\mathrm{TP}$ concentration increased from 0.09 to $0.21 \mathrm{mg} \mathrm{PL}^{-1}$. Together with the changes in $\mathrm{NO}_{3}$ and TP concentrations, the turbidity increased from 8 to $57 \mathrm{FTU}$, the TRP concentration decrease from 0.06 to $0.02 \mathrm{mg} \mathrm{PL}^{-1}$ and the conductivity decreased from 235 to $122 \mathrm{mS} \mathrm{cm}^{-1}$ (Fig. S4). 

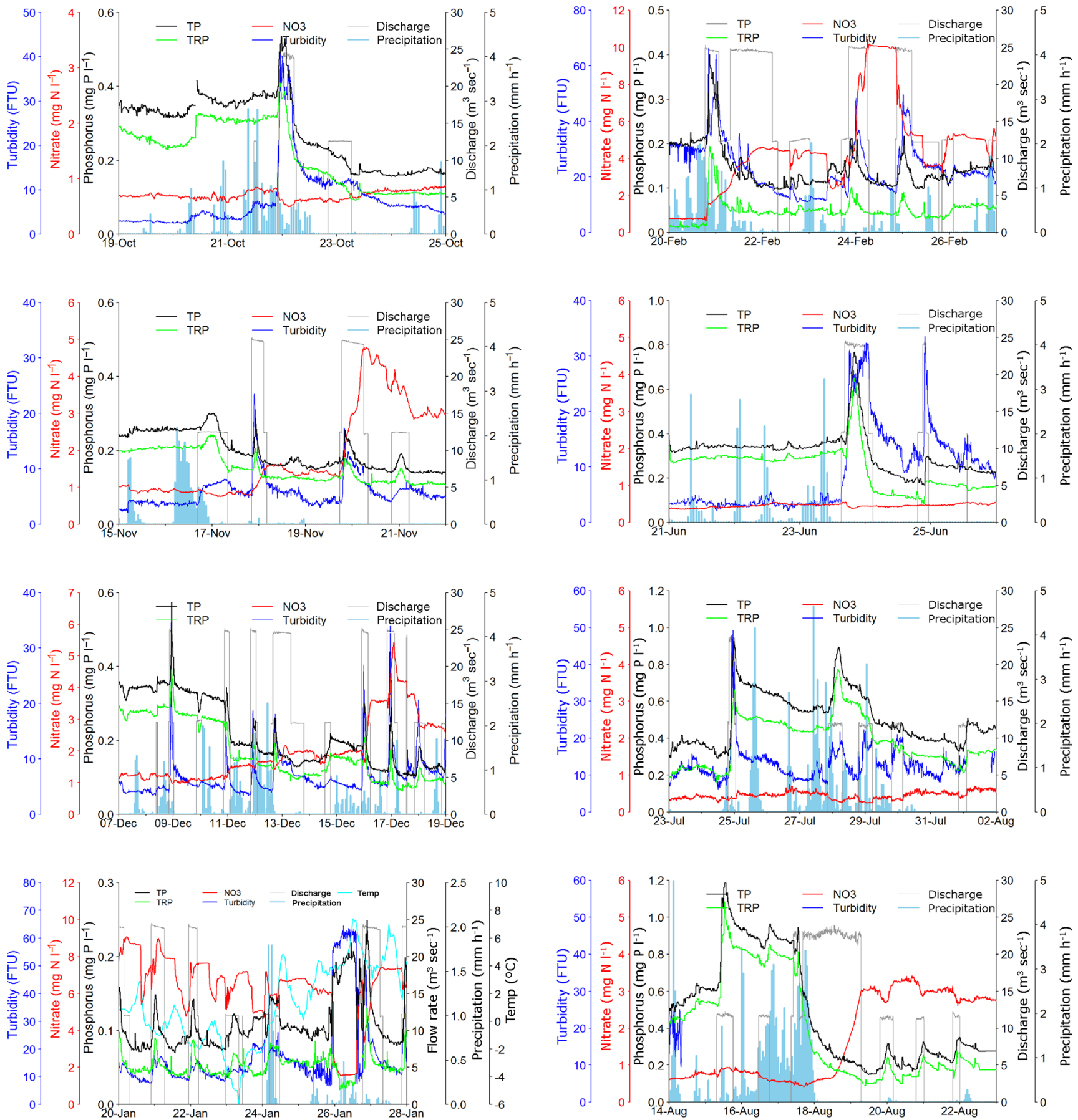

Figure 4. Examples of surface water $\mathrm{NO}_{3}$, TP, and turbidity dynamics at the pumping station Blocq van Kuffeler during meteorological events between October 2014 and August 2015 together with the pumping regime and precipitation (in $\mathrm{mm} \mathrm{h}^{-1}$ ). The January event demonstrates the effect of freeze-thaw on the nutrient concentrations, while the other events show the nutrient dynamics upon rainfall events.

\subsection{Decomposition of high-frequency nitrate data}

As shown in Sect. 3.2, $\mathrm{NO}_{3}$ concentrations were low from the start of the monitoring period until the rainfall event on 15 November and during April the $\mathrm{NO}_{3}$ concentrations decreased again. Precipitation events before mid-November and after April only had a minor influence on the $\mathrm{NO}_{3}$ concentration. For the period between 15 November and 30 April a transfer function-noise modelling of hourly $\mathrm{NO}_{3}$ concentrations reveals that the model can relate quite a large part of the dynamics to rainfall: the coefficient of determi- 
Table 2. Rainfall events and response of $\mathrm{NO}_{3}$ concentration (in $\mathrm{mg} \mathrm{NL}^{-1}$ ).

\begin{tabular}{llccc}
\hline $\begin{array}{l}\text { Rainfall } \\
\text { event }\end{array}$ & Date & $\mathrm{mm}$ & $\begin{array}{c}\mathrm{NO}_{3} \\
\text { concentration } \\
\text { before event }\end{array}$ & $\begin{array}{c}\text { Maximum } \mathrm{NO}_{3} \\
\text { concentration } \\
\text { after event }\end{array}$ \\
\hline 1 & 20-23 Oct & 31 & 0.7 & 0.8 \\
2 & 3-4 Nov & 16 & 0.8 & 0.9 \\
3 & 15-18 Nov & 23 & 0.8 & 4.6 \\
4 & 10-12 Dec & 29 & 1.0 & 5.3 \\
5 & 19-20 Dec & 24 & 2.4 & 5.9 \\
6 & 7-9 Jan & 14 & 3.0 & 5.8 \\
7 & 12-14 Jan & 24 & 4.1 & 9.0 \\
8 & 20-21 Feb & 26 & 0.8 & 10.4 \\
9 & 29 Mar-2 Apr & 43 & 0.8 & 6.1 \\
10 & 17-23 Jun & 40 & 0.2 & 0.5 \\
11 & 27-29 Jul & 47 & 0.5 & 0.7 \\
12 & 14-18 Aug & 87 & 0.6 & 3.4 \\
13 & 26-31 Aug & 59 & 2.4 & 4.7 \\
\hline
\end{tabular}

Table 3. Summary of TP and turbidity peaks, calculated as difference between the maximum value during the peak minus the value before the peak, induced by the pumping station.

\begin{tabular}{|c|c|c|c|c|}
\hline & $\begin{array}{l}\Delta \mathrm{TP} \\
\left(\mathrm{mg} \mathrm{L}^{-1}\right)\end{array}$ & $\begin{array}{l}\Delta \text { turbidity } \\
\text { (FTU) }\end{array}$ & $\begin{array}{l}\Delta \mathrm{TP} \\
\left(\mathrm{mg} \mathrm{L}^{-1}\right)\end{array}$ & $\begin{array}{l}\Delta \text { turbidity } \\
\text { (FTU) }\end{array}$ \\
\hline & 1 pump & 1 pump & 2 pumps & 2 pumps \\
\hline$n$ peaks & 72 & 79 & 59 & 60 \\
\hline Average & 0.06 & 4.4 & 0.13 & 22.1 \\
\hline Median & 0.04 & 4.4 & 0.10 & 21.1 \\
\hline P25 & 0.01 & 1.8 & 0.07 & 14.0 \\
\hline P75 & 0.08 & 8.3 & 0.14 & 29.2 \\
\hline Max & 0.58 & 26.2 & 0.61 & 52.0 \\
\hline Min & -0.01 & -1.5 & 0.03 & 5.9 \\
\hline
\end{tabular}

nation $R^{2}=0.7$. The measured time series together with the model simulation and the residual series are shown in Fig. 5.

Overall, the transfer model describes slow dynamics well; short-term dynamics cannot be related to rainfall with the transfer model and are described by the stochastic model. The estimated autoregressive coefficient $(\phi=0.98)$ is quite low given the high sampling interval of $1 \mathrm{~h}$, indicating that most of the temporal structure in the time series has been captured by the transfer model.

The estimated model parameters and their standard deviation are given in Table S1 in the Supplement. The estimated impulse response function for transferring an impulse of $1 \mathrm{~mm}$ rainfall into $\log -\mathrm{NO}_{3}$ concentration is given in Fig. S6. The smooth character of the function is due to predefined structure of the function, which is the Gamma distribution function. The time to peak is 5.4 days with a response of $0.033 \log \left(\mathrm{mg} \mathrm{NO}_{3}-\mathrm{N} \mathrm{mg} \mathrm{L}^{-1}\right)$, while $95 \%$ of the total response happens within 43 days. The time to peak as revealed by the TFN model matches well with the delay of

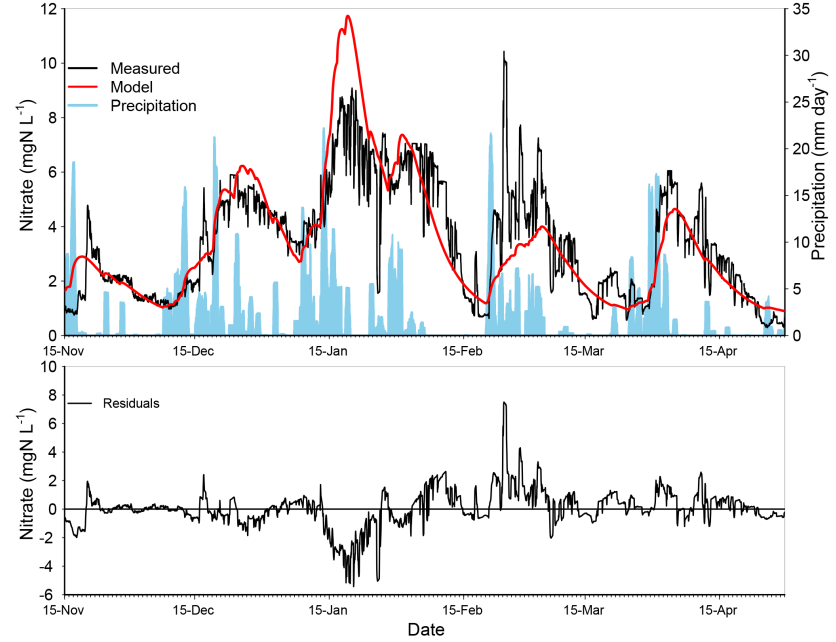

Figure 5. Measured and simulated $\mathrm{NO}_{3}$ concentrations and rainfall data (top panel); and residual $\mathrm{NO}_{3}$ series (bottom panel).

approximately 5 days between rainfall events and peak concentrations (Fig. 4).

The reference or baseline level follows from the model estimation and has a value of $\mu=-1.13$, or back-transformed from logarithm: $e^{-1.13}=0.32 \mathrm{mg} \mathrm{NL}^{-1}$, which means that after a long no-rain period, the $\mathrm{NO}_{3}$ concentration will decline to $0.32 \mathrm{mg} \mathrm{N} \mathrm{L}^{-1}$. The current time series does not include seasonal patterns; during spring and summer season the $\mathrm{NO}_{3}$ concentration cannot be related to rainfall only. The groundwater levels drop below the tube drain levels (i.e. precipitation may not lead to discharge) and denitrification or in-stream nutrient uptake processes reduce the $\mathrm{NO}_{3}$ concentration, so other driving forces and non-linearity have to be included in the TFN model for modelling the summer season.

\subsection{Nutrient loads and fluxes at polder outlet}

The annual loads based on the high-frequency data set equalled $19500 \mathrm{~kg}$ for $\mathrm{TP}, 388500 \mathrm{~kg}$ for $\mathrm{NO}_{3}-\mathrm{N}$, and $1788000 \mathrm{~kg}$ for SS, which corresponds to $0.98 \mathrm{~kg} \mathrm{ha}^{-1}$ for TP, $19.4 \mathrm{~kg} \mathrm{ha}^{-1}$ for $\mathrm{NO}_{3}-\mathrm{N}$, and $89.4 \mathrm{~kg} \mathrm{ha}^{-1}$ for SS (Fig. 3). The TP load during the winter months (OctoberMarch) was almost equal to the load during the summer months (April-September), while for $\mathrm{NO}_{3}$ almost $80 \%$ of the annual load occurred during the winter months, with January and February as most important months. The annual loads calculated from the grab sample data equalled $18200 \mathrm{~kg}$ for TP and $372500 \mathrm{~kg}$ for $\mathrm{NO}_{3}-\mathrm{N}$. The annual baseline TP load after separation of the TP concentration peaks was $15400 \mathrm{~kg}$. The difference between the total load and the baseline load equalled $4100 \mathrm{~kg}$; i.e. $21 \%$ of the annual TP load can be attributed to resuspension of TP due to changes in water flow induced by the pumping station. 
During the period from 1 October 2014 to 1 April 2015 the cumulative TP load calculated from the grab sample data matched the baseline TP load and underestimated the highfrequency load with $17 \%$. The months December and January showed the largest difference between the grab sample load and the high-frequency load. The winter low-frequency $\mathrm{NO}_{3}$ load overestimated the high-frequency load by $6.5 \%$, mainly due to a higher monthly low-frequency load in February. From May to mid-August 2015 there was almost no $\mathrm{NO}_{3}$ load. In August and September the grab sample load was lower than the high-frequency load. The annual grab sample load underestimated the high-frequency load with $4 \%$.

Time series of TP and $\mathrm{NO}_{3}$ concentrations in grab samples at the Blocq van Kuffeler pumping station over the period 2000-2015 are given in Fig. 6. The red lines in Fig. 6 show the LOWESS trend line and the black lines show the Theil-Sen slope over the period 2000-2015. The $\mathrm{NO}_{3}$ concentration showed no significant upward or downward trend over the period 2000-2015. The time series of TP concentration showed different trends over the period 2000-2015. After a period with minor increase for 2000 to 2009, the LOWESS trend line reveals a decline in TP concentrations in the period 2009-2010 followed by an increase from 2011 to 2015. The Theil-Sen slope showed a decline of TP concentration $\left(-0.0053 \mathrm{mg} \mathrm{PL}^{-1}\right.$ per year) over the years 2000 2015. This downward trend was significant according the seasonal Mann-Kendall trend tests.

The blue and green lines give the Theil-Sen slopes for the periods 2000-2008 and 2009-2015, respectively, before and after renovation of the pumping station. Where the Theil-Sen slope showed a decline of TP concentration over the years 2000-2015, it showed upward trends of $0.0023 \mathrm{mg} \mathrm{PL}^{-1}$ per year and $0.011 \mathrm{mg} \mathrm{PL}^{-1}$ per year over the separate periods 2000-2008 and 2009-2015, respectively. The upward trend for the period 2009-2015 was significant according the seasonal Mann-Kendall trend tests. The $\mathrm{NO}_{3}$ concentrations showed no significant upward or downward trend over the separate periods 2000-2008 and 2009-2015.

\section{Discussion}

\subsection{Identification of nutrients sources and dynamics in nutrient concentrations}

\subsubsection{Nitrate}

The high-frequency $\mathrm{NO}_{3}$ data showed a seasonal trend with higher concentrations during winter compared summer. Low-frequency surface water data showed high $\mathrm{NO}_{3}$ concentrations at the outlet of the agriculture-dominated areas within the drainage area during winter months (Fig. S1), whereas the groundwater has low $\mathrm{NO}_{3}$ concentrations (Fig. S3). From this, it is clear that $\mathrm{NO}_{3}$ in the surface water at the polder outlet has an agricultural source. An increase
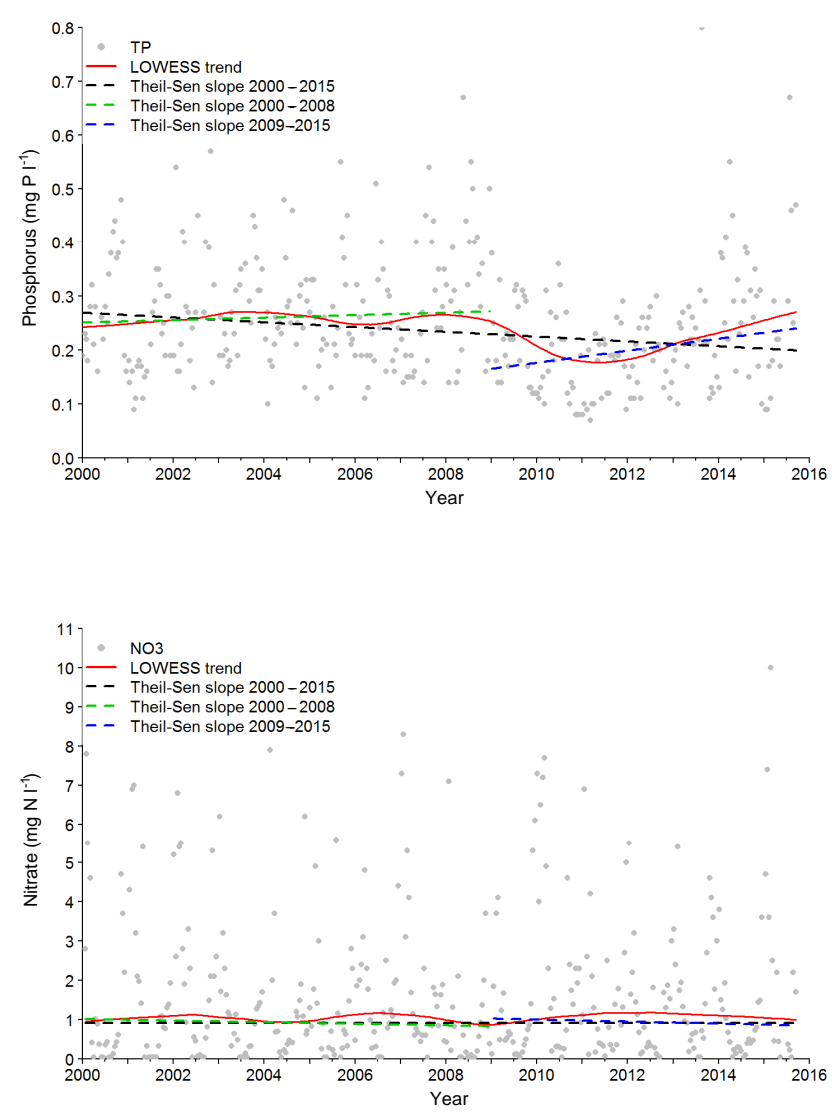

Figure 6. Trends in $\mathrm{TP}$ and $\mathrm{NO}_{3}$ concentrations over the period 2000-2015 at location 1 (Blocq van Kuffeler).

of $\mathrm{NO}_{3}$ concentrations from summer to winter is observed in a large majority of agriculture-dominated headwater in the Netherlands (Rozemeijer et al., 2014) and natural catchments elsewhere (Wade et al., 2012). Catchments where $\mathrm{NO}_{3}$ concentrations are controlled by a combination of effluent loads from sewage treatment works and dilution by rainfall commonly show a decline in $\mathrm{NO}_{3}$ from summer to winter (Bowes et al., 2015; Wade et al., 2012). The $\mathrm{NO}_{3}$ pattern is therefore thought to be due to a combination of interflow or shallow draining groundwater with high fertiliser or manure inputs and $\mathrm{NO}_{3}$ enrichment during autumn and winter. Increased crop uptake of $\mathrm{NO}_{3}$ during the growing season combined with the effect of in-stream processes result in declined $\mathrm{NO}_{3}$ concentrations during the summer months.

The annual $\mathrm{NO}_{3}$ load from the WWTP to the Lage Vaart is approximately $4 \%$ of the $\mathrm{NO}_{3}$ export load at the polder outlet. The low $\mathrm{NO}_{3}$ concentrations during the summer months and the rapid increase after a very wet period during August additionally indicate that the influence of sewage effluent on the $\mathrm{NO}_{3}$ concentrations is limited. The discharge from the channel that drains the nature area Oostvaardersplassen (Fig. 1, location 6) enters the Lage Vaart between the WWTP and the pumping station and is 2 to 3 times higher than the 
discharge from the WWTP. This implies that there is limited flow of the WWTP effluent towards the pumping station during no pumping conditions.

Beside the seasonal variation, we structurally observed an increase of $\mathrm{NO}_{3}$ concentrations after intensive rainfall events during the winter months. A reduction in $\mathrm{NO}_{3}$ concentrations coinciding with periods of intensive rainfall is commonly reported in high-frequency monitoring studies in natural catchments and attributed to dilution of the surface water by surface run-off (Bowes et al., 2015; Rozemeijer et al., 2010). Our structurally observed increase implies that runoff, which dilutes the $\mathrm{NO}_{3}$ concentration of the surface water, does not commonly occur in the polder. Dilution of the $\mathrm{NO}_{3}$ concentration upon rainfall was only observed during the thaw on 25 January. Soil freeze-thaw processes significantly increase the potential erosion during run-off events that follow thaw in hill slope areas (Ferrick and Gatto, 2005) but also in relatively flat areas (Gentry et al., 2007). Where during normal conditions rainfall infiltrates into the soil, the thaw and precipitation on 25 January likely resulted in runoff. This temporally diluted the $\mathrm{NO}_{3}$ concentration and conductivity and increased the TP concentration and turbidity.

During normal conditions with soil temperatures above $0{ }^{\circ} \mathrm{C}$, rainfall initiates a sudden increase of quick interflow via subsurface tube drains, cracks, or other macropores to the Lage Vaart channel water, which results in leaching for $\mathrm{NO}_{3}$ stored in the soil profile to the surface water.

This is confirmed by the TFN model, which showed that quite a large part of the $\mathrm{NO}_{3}$ dynamics during the winter months can be related to rainfall. The results in Fig. 5 show that during no-rain periods the decline in concentration is modelled well. The various periods of rainfall show different results: in December the increase in concentration is modelled well, in January the concentration is overestimated, while in February and March the concentration is underestimated. The overestimation in January can be explained by dilution in combination with a decrease of in the $\mathrm{NO}_{3}$ stock stored in the soil profile due to leaching with rain during previous months. The largest positive residuals appeared on 2426 February. Recent manure application is a plausible explanation for the underestimation of measured concentrations in February and March (see Sect. 3.3). The largest negative residuals appeared during the thaw on 25 and 26 January. The residuals of the TFN model help to get a better understanding of the dynamic $\mathrm{NO}_{3}$ behaviour of the polder catchment.

\section{Drainage water}

The tube drain water in the Flevoland polder contains relatively high $\mathrm{NO}_{3}$ concentrations. Meinardi and Van den Eertwegh (1997) ran a monitoring programme on tube drain water composition at 14 farms in the Flevoland polder during 1992-1995 and reported concentrations between 5 and $25 \mathrm{mg} \mathrm{NL}^{-1}$. Another monitoring programme on nutrient concentration of tube drain water at six farms in Flevoland from 2004 to 2008 gave farm-average $\mathrm{NO}_{3}$ concentrations of 14-18 $\mathrm{m} \mathrm{N} \mathrm{L}^{-1}$ (van Boekel et al., 2012). These concentrations can only explain the observed $\mathrm{NO}_{3}$ concentration at the pumping station during wet conditions when the tube drain water is the dominant contributor of the Lage Vaart channel water. Groundwater levels within the polder are commonly low and tube drainage is rare during the summer and early autumn (Van den Eertwegh, 2002; Groen, 1997). In autumn, when evapotranspiration decreases, the groundwater levels rise upon rainfall events to around or above the level of the tube drains, which are present at a depth of $0.95 \mathrm{~m}$ below the soil surface, and this initiates drain discharge. This is illustrated by the measured groundwater levels within the Lage Afdeling drainage area (Fig. S7) that shows a direct response of the groundwater level on rainfall combined with a seasonal trend that shows rising groundwater levels during the months October and November and quite stable levels from December to March. Rainfall events between the start of the monitoring and mid-November and between April and midAugust did not result in tube drain discharge. The low $\mathrm{NO}_{3}$ concentration of the surface water during these periods are thus explained by the absence of tube drain discharge. Extensive rainfall during the second half of August resulted in a rising of the groundwater level close to the tube drain level (Fig. S7) and thus to leaching of $\mathrm{NO}_{3}$, stored in the soil profile, to the surface water. As our TFN model is weak in explaining the processes that might control $\mathrm{NO}_{3}$ concentration such as biogeochemical processes in surface waters we did not include the summer period in our model.

\section{Preferential transport}

The high-frequency data showed a quick response of the $\mathrm{NO}_{3}$ concentration at the pumping station to rainfall once the groundwater level is at the tube drain level. This can be explained by the presence of cracked clay soils that results in a rapid response of drainage to rainfall events in winter (Groen, 1997; Van den Eertwegh, 2002). Preferential transport of water and nutrients through cracks and macropores is known to play an important role in heavy clay soils (e.g. Van der Salm et al., 2012). Due to regular plowing rainwater easily infiltrates into the top soil layer where exchange of $\mathrm{NO}_{3}$ from manure, fertilisers, and plant debris occurs. The top soil or plough layer is commonly well aerated, and therefore, quite optimal for conversion of organic nitrogen and ammonium to $\mathrm{NO}_{3}$. After leaching of this water from the plough layer to the cracked soil layer it quickly contributes to tube drain discharge. Due to short residence time of this water in the soil, the influence of denitrification on the $\mathrm{NO}_{3}$ concentration is limited. This implies that the $\mathrm{NO}_{3}$ concentration at the polder outlet and the related export load from the polder are strongly controlled by quick interflow including tube drain discharge during the winter months.

The period of 5 days between rainfall event and peak in the $\mathrm{NO}_{3}$ concentration at the pumping station is representative 
for the average residence time of water in the Lage Afdeling drainage area during wet conditions. Catchment mean residence times are much shorter during wet periods compared dry periods (Van der Velde et al., 2012). The 5 days travel time of the water in the field ditches, sub-channels and main channel during wet conditions is in line with model calculated mean annual residence times of water in the Lage Vaart main channel of 6.6 days (Van den Eertwegh, 2002).

\subsubsection{Phosphorus}

In contrast to the $\mathrm{NO}_{3}$ concentration, the TP concentration at the pumping station decreased after the wet periods (Fig. 2c). The interflow discharge via subsurface tube drains, cracks or other macropores that resulted in an increase of $\mathrm{NO}_{3}$ concentrations diluted the TP concentrations. Likely this can be attributed to the relative decrease of the groundwater contribution to the channel water during periods of increased interflow discharge. This indicates that the sources of TP in the channel water at the polder outlet can largely be attributed to exfiltration of P-rich groundwater that occurs throughout the year, presumably in combination with effluent loads from the WWTP and biogeochemical remobilisation of P from channel sediments during the summer and autumn. The low DRP : TP ratio of the surface water within the Lage Afdeling as observed during the first half-year of 2014 and 2015 (Fig. S1) can be explained by transition of dissolved P to particulate $\mathrm{P}$ at the groundwater-surface water interface. This commonly occurs after exfiltration of anaerobic groundwater into surface water due to oxidation processes (e.g. van der Grift et al., 2014; Baken et al., 2015).

The annual TP load from the WWTP to the Lage Vaart is approximately $27 \%$ of the TP export load at the polder outlet. As discussed previously for $\mathrm{NO}_{3}$, the effect of the WWTP on the $\mathrm{NO}_{3}$ concentration at the pumping station seems to be small. For TP, however, the WWTP load cannot be neglected. The discharge water from the Oostvaardersplassen has relatively high TP concentrations (Fig. S1) and may contribute to the increase in TP concentration at the pumping station during no pumping periods. The source of the TP in the Oostvaardersplassen is groundwater and feces of wildlife. The Oostvaardersplassen is an important wintering area for birds that import nutrients from elsewhere.

The high DRP : TP ratios of the low-frequency monitoring programme during the second half-year of 2014 and the summer of 2015 indicates that mineralisation of organic P from algae or plant debris, or release of DRP from bed sediments can be considered as an additional $\mathrm{P}$ source during summer and autumn when the TP concentration reached a maximum level between 0.8 and $1.2 \mathrm{mg} \mathrm{PL}^{-1}$. Mineralisation of organic $\mathrm{P}$ mainly occurs after the growing season and the release of DRP from bed sediments is reported during summer and autumn due to temperature and redox-dependent biogeochemical remobilisation processes for lakes (e.g. Lavoie and Auclair, 2012; Boers and van Hese, 1988), wetlands, fens and floodplain soils (e.g. Zak et al., 2006; Loeb et al., 2008) but also for streams and rivers (e.g. Duan et al., 2012; Jarvie et al., 2008). Low $\mathrm{O}_{2}$ concentrations in the water column are reported as an indicator for remobilisation of $\mathrm{P}$ from bed sediments (Geurts et al., 2013). The surface water at low-frequency monitoring locations showed a decline of the $\mathrm{O}_{2}$ concentrations during the summer and autumn months (Fig. S1), thus indicating that biogeochemical remobilisation may occur in the channels of the Lage Afdeling.

Surface run-off as a source of $\mathrm{P}$ in the surface water was only observed at the end of the freeze-thaw cycle on 2526 January. The TRP did not increase during this event, suggesting the TP largely existed of non-liable organic P. Runoff is generally not an important transport process controlling $\mathrm{P}$ dynamic in the polder catchment.

\section{Resuspension of particulate $P$}

The increase of the TP concentration and turbidity during operation of the pumping station and the larger increase during pumping with two pumps compared to one pump (Table 3) indicate that the increase of the TP concentration is related to resuspension of $\mathrm{P}$ from bed sediments due to increased flow velocities. During no-pumping conditions, an erodible layer builds up by sedimentation of particulate $P$. When the water flow velocities in the main channel increase upon pumping, the $\mathrm{P}$ becomes suspended and transported downstream. The largest increase of the TP concentration during pumping with two pumps after longer periods without pumping and the decreasing TP peaks with subsequent pumping events supports this mechanism.

Resuspension of particulate $\mathrm{P}$ retained by sediments during high discharge events is an important transport mechanism in natural catchments (e.g. Evans et al., 2004; Mulholland et al., 1985; Nyenje et al., 2014; Haygarth et al., 2005; Palmer-Felgate et al., 2008). Our data shows that this mechanism is also relevant for $\mathrm{P}$ transport in polders where flow velocities vary more abruptly and are maximised by the capacity of the pumping station. The changes in TP concentration during pumping are, however, significantly lower than reported during peak water discharge amongst storms in natural catchments. For an agriculture-dominated lowland catchment in the Netherlands, Rozemeijer et al. (2010) reported a mean increase in TP concentration during discharge from 0.15 to $0.95 \mathrm{mg} \mathrm{PL}^{-1}$ coming from 47 rainfall events over a year. Particulate P (PP) increases up to a factor of 100 were reported by Stutter et al. (2008) in response to storm events. Evans et al. (2004) measured PP concentrations up to $3.93 \mathrm{mg} \mathrm{PL}^{-1}$ in al lowland stream during high discharge conditions while the mean concentration equalled $0.1 \mathrm{mg} \mathrm{PL}^{-1}$. Haygarth et al. (2005) reported 10 to 20 times higher mean TP concentrations during storm flow conditions compared to base flow conditions. With data from 76 storms, Correll et al. (1999) showed that concentrations of PP increased up to 3 orders of magnitude during storms. 
These changes are all considerably larger than the average factor of 1.30 and 1.83 that we observed at the pumping station during pumping with one and two pumps, respectively. The $\mathrm{P}$ export from natural catchments during pulses at high flow in less than $10 \%$ of the time may amount to about $80 \%$ of the annual export (Kaushal et al., 2014). With 143 pumping events during the period from October 2014 to September 2015, discharge-related changes that lead to resuspension of $\mathrm{P}$ appear more frequent in this polder catchment compared to natural catchments. As only $21 \%$ of the annual TP export load can be related to resuspension this cannot be considered as the dominant $\mathrm{P}$ transport mechanism. The artificial pumping regime that buffers high flows in polder area thus results in a high potential of polder areas to retain $\mathrm{P}$ by sedimentation of PP. Consequently, this may result in a higher potential of polder areas for DRP release from the bed sediments during summer months by biogeochemical remobilisation, which attributes to TP export loads during the summer period. Therefore, it can be concluded that $\mathrm{P}$ transport mechanisms in polder catchment can be characterised as less incidental and peak flow controlled and more controlled by biogeochemical remobilisation from bed sediments than those from natural catchments.

\subsection{Incidental nutrient losses to surface water after manure application}

The $\mathrm{NO}_{3}$ concentration peaked at the polder outlet on 24 February, 4 days after an intensive rainfall event that marked the end of a relative dry period that started early February. The increase of the $\mathrm{NO}_{3}$ concentration is almost 2 times higher compared to the other peaks in $\mathrm{NO}_{3}$ concentration after a rainfall event (Table 2). This suggests that the $\mathrm{NO}_{3}$ peak of $10.4 \mathrm{mg} \mathrm{NL}^{-1}$ was caused by an incidental loss after manure application that started on 1 February. The TFN model revealed high residual $\mathrm{NO}_{3}$ concentrations up to almost $8 \mathrm{mg} \mathrm{NL}^{-1}$ during this $\mathrm{NO}_{3}$ peak that cannot be explained by rainfall (Fig. 5). The $\mathrm{NO}_{3}$ concentration peaks on 27 February and 3 March also showed large positive residuals of 4.2 and $3.4 \mathrm{mg} \mathrm{N}^{-1}$, respectively. The wet period in January resulted, however, in predicted $\mathrm{NO}_{3}$ concentrations that were higher than the measured concentrations. The negative residuals in January can be explained by leaching of the $\mathrm{NO}_{3}$ stored in the soil profile during the winter season in combination with the appearance of some degree of dilution of the remaining $\mathrm{NO}_{3}$ by precipitation water during this period. Dilution of the $\mathrm{NO}_{3}$ concentration upon rainfall events commonly observed in catchments (e.g. Rozemeijer et al., 2010; Wade et al., 2012). A plausible explanation for the large positive residuals in February and March is recent manure application that started on 1 February and temporary soil storage of applied $\mathrm{N}$ during the first dry weeks of February.

The TP concentration peaked on 21 February during the beginning of the rainfall event, simultaneously with a tur- bidity peak after the start-up of the pumps following upon a relatively dry period of more than 1 week without pumping (Fig. 4). It is, therefore, not likely that this peak was caused by an incidental loss after manure application but caused by hydrodynamic resuspension of the Lage Vaart bed sediment. The absence of a TP peak after the rainfall event on 21-22 February can be attributed to the soil characteristics of the area. We already discussed that the water quality at the polder outlet is strongly controlled by quick interflow via tube drains or cracks and that surface run-off only influenced the water quality when it rained during the end of a freezethaw cycle. Although it is known that tube drain discharge after rainfall events in combination with recent manure application on cracked clay soils may contain significant TP concentrations (Van der Salm et al., 2012), these peaks did not appear at the polder outlet. Several other studies indicate elevated TP concentrations in drain and trench flow within a few weeks after application of fertilisers or liquid farm manure (Hodgkinson et al., 2002; Simard et al., 2000; Djodjic et al., 2000). It is unknown if these peaks appear after rainfall events in the tube drain discharge or in the receiving field ditches in the Lage Afdeling drainage area. Therefore, it is unclear if the absence of TP peaks simultaneously with the $\mathrm{NO}_{3}$ peaks at the polder outlet can be attributed to sedimentation of PP from agricultural sources in the field ditches or sub-channels where it may become a source for DRP release from bed sediments during the summer and autumn months or that there is almost no particulate or dissolved P leaching from the topsoil to the surface water due to the sorption capacity of the topsoil. From other lowland areas it is known that the dissolved $\mathrm{P}$ loads to surface water from tube drains and shallow groundwater discharge are low due to precipitation with Fe hydroxides with a high affinity to retain $\mathrm{P}$, at the oxic/anoxic interface around the tube drains and ditch sediment (van der Grift et al., 2014; Baken et al., 2015).

\subsection{Water quality affected by the operational management of the pumping station}

Since the renovation of the pumping station in the autumn of 2008 , it runs typically overnight during normal meteorological conditions, for reasons of cheaper power supply. The low-frequency sampling is always performed during daytime. The distribution of pumping hours and sampling moments over the day during the period October 2014September 2015 and box plots of measured TP concentrations over the day during the months January and February 2015 are shown in Fig. S8. These 2 months were selected because box plots for longer time series are dominated by the seasonal trends in the TP concentration. The median, quartile and maximum TP concentrations were higher during night hours than during daytime. As a result, the monitoring programme systematically misses the TP peak that occurs during pumping and consequently does not measure diurnal cycles in water quality caused by the pumping sta- 
tion. The reported time series from the low-frequency sampling programme is, thus, not fully representative for the TP concentration at the polder outlet. As a consequence, export fluxes from the polder as calculated from low-frequency sample data underestimate the true export P-loads (Fig. 3). The $\mathrm{NO}_{3}$ concentration showed no structural response on pumping, further illustrating the importance of resuspension of $\mathrm{P}$ by pumping.

The preferred timing of sampling during regular workinghours is also critical for trend detection in the resulted data set time series (Fig. 6). Trend analysis before and after replacement of the diesel engines compared with trend analysis over the years 2000-2015 indicates that the trend of slightly decreasing concentrations over the years 2000-2015 may be caused by the sudden decrease of concentrations after renovation of the pumping station, which is an artefact of a change in pumping regimes.

The number of diesel powered pumping stations in the Netherlands has rapidly declined during the last decades. There were around 200 diesel or hybrid (diesel + electric) powered pumping stations in operation in 1990. Currently, there are only 40 remaining and these pumping stations have mainly a function for emergency situations (Gemalen, 2015). During the same period, electric powered pumping stations have been equipped with automatic switching systems. Nowadays, a large majority of pumping stations operates predominantly during night hours. As the pumping station is the outlet of a (artificial) water system it is often a monitoring location for surface water quality as well. The renovation of pumping stations may thus have had a substantial impact on reported trends in water quality on a regional or even a national scale.

\section{Conclusions}

High-frequency monitoring at the outlet of an agriculturedominated lowland water system combined with lowfrequency monitoring at several other locations in the polder appears to be an effective tool to reveal difficult to notice responses in surface water quality. $\mathrm{P}$ and $\mathrm{NO}_{3}$ react differently. Conclusions regarding $\mathrm{P}$ are the following:

- The P retention potential of the polder water systems is enhanced compared to natural catchments due to the artificial pumping regime that prevents high discharge flow and therefore limits resuspension of particulate $\mathrm{P}$.

- Groundwater seepage, biogeochemical remobilisation and wastewater treatment plant effluent are sources of $\mathrm{TP}$ in the surface water. The relative importance of these sources, however, cannot be determined.

- Rainfall events do not results in TP concentration peaks. Transport of particulate $\mathrm{P}$ that originates from groundwater and (agricultural) drains discharge is strongly re- tained but particulate $\mathrm{P}$ can be remobilised due to biogeochemical processes in the sediment layer at other moments. This makes it difficult to link agricultural practice to $\mathrm{P}$ concentrations in the surface water and this should be accounted for when judging measures to reduce P loads from agriculture.

- The artificial pumping regime and high retention capacity of polder catchments, however, enables the potential for measures to reclaim $P$ from the water systems after being leached from the soil but before being transported to downstream surface water bodies.

Conclusions with respect to $\mathrm{N}$ :

- the $\mathrm{NO}_{3}$ load to surface water originates from subsurface drains in the agricultural area, likely in combination with quick interflow via clay cracks, that start discharging upon intensive rainfall events and result in a quick response of the $\mathrm{NO}_{3}$ concentration at the polder outlet;

- intensive rainfall events within a few weeks after manure application in February results in incidental losses of $\mathrm{NO}_{3}$.

In general it can furthermore be concluded that

- surface run-off is generally not an important transport mechanism controlling $\mathrm{NO}_{3}, \mathrm{P}$ and $\mathrm{SS}$ dynamics in the polder catchment, expect at the end of a freeze-thaw cycle;

- the timing of sampling relative to the operating hours of a pumping station affects the concentration of TP and SS and this should be accounted for when calculating $\mathrm{P}$ export loads, determining trends in water quality or when evaluating water quality against ecological thresholds and standards.

\section{The Supplement related to this article is available online at doi:10.5194/hess-20-1851-2016-supplement.}

Acknowledgements. The Regional Water Authority Zuiderzeeland is gratefully acknowledged for the financial support for installation and maintenance of the high-frequency monitoring station and providing the water quality and groundwater level data. The useful comments of two anonymous reviewers are greatly appreciated. Funding of the project was provided by Deltares (project SO2015: from catchment to coast).

Edited by: B. Kronvang 


\section{References}

Akkermans, S. and Hermans, B.: Position paper manure, Stichting Natuur \& Milieu, Utrecht, the Netherlands, 2014.

APHA-AWWA-WPCF: Standard Methods for the Examination of Water and Waste Water, edited by: Clesceri, G., Trussell, American Public Health Association, Washington, D.C, 1268 pp., 1989.

Baken, S., Verbeeck, M., Verheyen, D., Diels, J., and Smolders, E.: Phosphorus losses from agricultural land to natural waters are reduced by immobilization in iron-rich sediments of drainage ditches, Water Res., 71, 160-170, 2015.

Berendrecht, W. L., Heemink, A. W., van Geer, F. C., and Gehrels, J. C.: Decoupling of modeling and measuring interval in groundwater time series analysis based on response characteristics, J. Hydrol., 278, 1-16, doi:10.1016/S0022-1694(03)00075-1, 2003.

Bieroza, M. Z., Heathwaite, A. L., Mullinger, N. J., and Keenan, P. O.: Understanding nutrient biogeochemistry in agricultural catchments: The challenge of appropriate monitoring frequencies, Environ. Sci. Process. Imp., 16, 1676-1691, doi:10.1039/c4em00100a, 2014.

Boers, P. C. M. and van Hese, O.: Phosphorus release from the peaty sediments of the Loosdrecht Lakes (The Netherlands), Water Res., 22, 355-363, 1988.

Bouwman, A. F., Bierkens, M. F. P., Griffioen, J., Hefting, M. M., Middelburg, J. J., Middelkoop, H., and Slomp, C. P.: Nutrient dynamics, transfer and retention along the aquatic continuum from land to ocean: towards integration of ecological and biogeochemical models, Biogeosciences, 10, 1-22, doi:10.5194/bg10-1-2013, 2013a.

Bouwman, L., Goldewijk, K. K., Van Der Hoek, K. W., Beusen, A. H. W., Van Vuuren, D. P., Willems, J., Rufino, M. C., and Stehfest, E.: Exploring global changes in nitrogen and phosphorus cycles in agriculture induced by livestock production over the 1900-2050 period, P. Natl. Acad. Sci. USA, 110, 20882-20887, doi:10.1073/pnas.1012878108, 2013b.

Bowes, M. J., Jarvie, H. P., Halliday, S. J., Skeffington, R. A., Wade, A. J., Loewenthal, M., Gozzard, E., Newman, J. R., and Palmer-Felgate, E. J.: Characterising phosphorus and nitrate inputs to a rural river using high-frequency concentration-flow relationships, Sci. Total Environ., 511, 608620, doi:10.1016/j.scitotenv.2014.12.086, 2015.

Box, G. E. P. and Jenkins, G. M.: Time Series Analysis: Forecasting and Control, Holden-Day, San Francisco, 575 pp., 1970.

Cassidy, R. and Jordan, P.: Limitations of instantaneous water quality sampling in surface-water catchments: Comparison with nearcontinuous phosphorus time-series data, J. Hydrol., 405, 182193, doi:10.1016/j.jhydrol.2011.05.020, 2011.

Cirmo, C. P. and McDonnell, J. J.: Linking the hydrologic and biogeochemical controls of nitrogen transport in near-stream zones of temperate-forested catchments: a review, J. Hydrol., 199, 88120, doi:10.1016/S0022-1694(96)03286-6, 1997.

Cleveland, W. S.: Robust locally weighted regression and smoothing scatterplots, J. Am. Stat. Assoc., 74, 829-836, 1979.

Correll, D. L., Jordan, T. E., and Weller, D. E.: Transport of nitrogen and phosphorus from Rhode River watersheds during storm events, Water Resour. Res., 35, 2513-2521, 1999.

Djodjic, F., Ulén, B., and Bergström, L.: Temporal and spatial variations of phosphorus losses and drainage in a structured clay soil, Water Res., 34, 1687-1695, doi:10.1016/S0043-1354(99)003127, 2000.
Duan, S., Kaushal, S. S., Groffman, P. M., Band, L. E., and Belt, K. T.: Phosphorus export across an urban to rural gradient in the Chesapeake Bay watershed, J. Geophys. Res.-Biogeo., 117, G01025, doi:10.1029/2011JG001782, 2012.

EC: Council Directive 91/676/EEC of 12 December 1991 concerning the protection of waters against pollution caused by nitrates from agricultural sources, European Commission, Brussels, 1991.

EC: Councul Directive of 23 October 2000 establishing a framework for Community action in the field of water policy, European Commission, Brussels, 2000.

EC: The Water Framework Directive and the Floods Directive: Actions towards the 'good status' of EU water and to reduce flood risks European Commission, Brussels, 2015.

Evans, D. J., Johnes, P. J., and Lawrence, D. S.: Physico-chemical controls on phosphorus cycling in two lowland streams. Part 2 - The sediment phase, Sci. Total Environ., 329, 165-182, doi:10.1016/j.scitotenv.2004.02.023, 2004.

Ferrick, M. G. and Gatto, L. W.: Quantifying the effect of a freezethaw cycle on soil erosion: Laboratory experiments, Earth Surf. Proc. Land., 30, 1305-1326, doi:10.1002/esp.1209, 2005.

Fraters, B., Kovar, K., Willems, W., Stockmarr, J., and Grant, R.: Monitoring effectiveness of the EU Nitrates Directive Action Programmes. Results of the international MonNO3 workshop in the Netherlands, 11-12 June 2003, RIVM, Bilthoven, the Netherlands, 290 pp., 2005.

Gao, P.: Understanding watershed suspended sediment transport, Prog. Phys. Geogr., 32, 243-263, 2008.

Gemalen: available from: http://www.gemalen.nl/, last access: 12 May 2015.

Gentry, L. E., David, M. B., Royer, T. V., Mitchell, C. A., and Starks, K. M.: Phosphorus Transport Pathways to Streams in Tile-Drained Agricultural Watersheds, J. Environ. Qual., 36, 408-415, doi:10.2134/jeq2006.0098, 2007.

Geurts, J. J. M., Hetjens, H., and Lamers, L. P. M.: Remobilization of nutrients after un-deepening of lakes, Radbouduniversiteit Nijmegen, Nijmegen, 79 pp., 2013.

Griffioen, J., Vermooten, S., and Janssen, G.: Geochemical and palaeohydrological controls on the composition of shallow groundwater in the Netherlands, Appl. Geochem., 39, 129-149, doi:10.1016/j.apgeochem.2013.10.005, 2013.

Groen, K. P.: Pesticide leaching in polders, Field and model studies on cracked clays and loamy sand, Van land tot zee, Ministerie van Verkeer en Waterstaat, Directoraat-Generaal Rijkswaterstaat, Lelystad, 295 pp., 1997.

Halliday, S. J., Wade, A. J., Skeffington, R. A., Neal, C., Reynolds, B., Rowland, P., Neal, M., and Norris, D.: An analysis of longterm trends, seasonality and short-term dynamics in water quality data from Plynlimon, Wales, Sci. Total Environ., 434, 186-200, doi:10.1016/j.scitotenv.2011.10.052, 2012.

Haygarth, P. M., Wood, F. L., Heathwaite, A. L., and Butler, P. J.: Phosphorus dynamics observed through increasing scales in a nested headwater-to-river channel study, Sci. Total Environ., 344, 83-106, doi:10.1016/j.scitotenv.2005.02.007, 2005.

Hewlett, J. D. and Hibbert, A. R.: Moisture and energy conditions within a sloping soil mass during drainage, J. Geophys. Res., 68, 1081-1087, 1963. 
Hirsch, R. M. and Slack, J. R.: A Nonparametric Trend Test for Seasonal Data With Serial Dependence, Water Resour. Res., 20, 727-732, doi:10.1029/WR020i006p00727, 1984.

Hirsch, R. M., Slack, J. R., and Smith, R. A.: Techniques of trend analysis for monthly water quality data, Water Resour. Res., 18, 107-121, doi:10.1029/WR018i001p00107, 1982.

Hodgkinson, R. A., Chambers, B. J., Withers, P. J. A., and Cross, R.: Phosphorus losses to surface waters following organic manure applications to a drained clay soil, Agr. Water Manage., 57, 155173, doi:10.1016/S0378-3774(02)00057-4, 2002.

Huebsch, M., Grimmeisen, F., Zemann, M., Fenton, O., Richards, K. G., Jordan, P., Sawarieh, A., Blum, P., and Goldscheider, N.: Technical Note: Field experiences using UV/VIS sensors for high-resolution monitoring of nitrate in groundwater, Hydrol. Earth Syst. Sci., 19, 1589-1598, doi:10.5194/hess-19-15892015, 2015.

Jarvie, H. P., Mortimer, R. J. G., Palmer-Felgate, E. J., Quinton, K. S., Harman, S. A., and Carbo, P.: Measurement of soluble reactive phosphorus concentration profiles and fluxes in river-bed sediments using DET gel probes, J. Hydrol., 350, 261-273, 2008.

Johnes, P. J.: Uncertainties in annual riverine phosphorus load estimation: Impact of load estimation methodology, sampling frequency, baseflow index and catchment population density, J. Hydrol., 332, 241-258, doi:10.1016/j.jhydrol.2006.07.006, 2007.

Jones, T. D., Chappell, N. A., and Tych, W.: First Dynamic Model of Dissolved Organic Carbon Derived Directly from HighFrequency Observations through Contiguous Storms, Environ. Sci. Technol., 48, 13289-13297, doi:10.1021/es503506m, 2014.

Jordan, P., Arnscheidt, A., McGrogan, H., and McCormick, S.: Characterising phosphorus transfers in rural catchments using a continuous bank-side analyser, Hydrol. Earth Syst. Sci., 11, 372381, doi:10.5194/hess-11-372-2007, 2007.

Kaufmann, V., Pinheiro, A., and Castro, N. M. D. R.: Simulating transport of nitrogen and phosphorus in a Cambisol after natural and simulated intense rainfall, J. Contam. Hydrol., 160, 53-64, doi:10.1016/j.jconhyd.2014.02.005, 2014.

Kaushal, S. S., Mayer, P. M., Vidon, P. G., Smith, R. M., Pennino, M. J., Newcomer, T. A., Duan, S., Welty, C., and Belt, K. T.: Land use and climate variability amplify carbon, nutrient, and contaminant pulses: A review with management implications, J. Am. Water Resour. Assoc., 50, 585-614, doi:10.1111/jawr.12204, 2014.

Kirchner, J. W., Feng, X., Neal, C., and Robson, A. J.: The fine structure of water-quality dynamics: the (highfrequency) wave of the future, Hydrol. Process., 18, 1353-1359, doi:10.1002/hyp.5537, 2004.

Knotters, M. and van Walsum, P. E. V.: Estimating fluctuation quantities from time series of water-table depths using models with a stochastic component, J. Hydrol., 197, 25-46, doi:10.1016/S0022-1694(96)03278-7, 1997.

Lavoie, M. and Auclair, J.-C.: Phosphorus Mobilization at the Sediment-Water Interface in Softwater Shield Lakes: the Role of Organic Carbon and Metal Oxyhydroxides, Aquat. Geochem., 18, 327-341, doi:10.1007/s10498-012-9166-3, 2012.

LNV: Fourth Dutch Action Programme (2010-2013) concerning the Nitrates Directive, 91/676/EEC, The Hague, 50 pp., 2009.

Loeb, R., Lamers, L. P. M., and Roelofs, J. G. M.: Prediction of phosphorus mobilisation in inundated floodplain soils, Environ. Pollut., 156, 325-331, doi:10.1016/j.envpol.2008.02.006, 2008.
Meinardi, C. R. and Van den Eertwegh, G. A. P. H.: Investigations on tile drains in clayey regions of the Netherlands, Part II: Interpretation of data, RIVM, Bilthoven, The Netherlands, 169 pp., 1997.

Mulholland, P. J., Newbold, J. D., Elwood, J. W., Ferren, L. A., and Jackson, R. W.: Phosphorus Spiralling in a Woodland Stream: Seasonal Variations, Ecology, 66, 1012-1023, 1985.

Murphy, J. and Riley, J. P.: A modified single solution method for the determination of phosphate in natural waters, Anal. Chim. Acta, 27, 31-36, 1962.

Neal, C., Reynolds, B., Rowland, P., Norris, D., Kirchner, J. W., Neal, M., Sleep, D., Lawlor, A., Woods, C., Thacker, S., Guyatt, H., Vincent, C., Hockenhull, K., Wickham, H., Harman, S., and Armstrong, L.: High-frequency water quality time series in precipitation and streamflow: From fragmentary signals to scientific challenge, Sci. Total Environ., 434, 3-12, doi:10.1016/j.scitotenv.2011.10.072, 2012.

Nyenje, P. M., Meijer, L. M. G., Foppen, J. W., Kulabako, R., and Uhlenbrook, S.: Phosphorus transport and retention in a channel draining an urban, tropical catchment with informal settlements, Hydrol. Earth Syst. Sci., 18, 1009-1025, doi:10.5194/hess-181009-2014, 2014.

Palmer-Felgate, E. J., Jarvie, H. P., Williams, R. J., Mortimer, R. J. G., Loewenthal, M., and Neal, C.: Phosphorus dynamics and productivity in a sewage-impacted lowland chalk stream, J. Hydrol., 351, 87-97, doi:10.1016/j.jhydrol.2007.11.036, 2008.

Poor, C. J. and McDonnell, J. J.: The effects of land use on stream nitrate dynamics, J. Hydrol., 332, 54-68, doi:10.1016/j.jhydrol.2006.06.022, 2007.

Regelink, I. C., Koopmans, G. F., van der Salm, C., Weng, L., and van Riemsdijk, W. H.: Characterization of Colloidal Phosphorus Species in Drainage Waters from a Clay Soil Using Asymmetric Flow Field-Flow Fractionation, J. Environ. Qual., 42, 464-473, doi:10.2134/jeq2012.0322, 2013.

Rozemeijer, J. C. and Broers, H. P.: The groundwater contribution to surface water contamination in a region with intensive agricultural land use (Noord-Brabant, The Netherlands), Environ. Pollut., 148, 695-706, doi:10.1016/j.envpol.2007.01.028, 2007.

Rozemeijer, J. C., Van der Velde, Y., Van Geer, F. C., De Rooij, G. H., Torfs, P. J. J. F., and Broers, H. P.: Improving load estimates for NO3 and $\mathrm{P}$ in surface waters by characterizing the concentration response to rainfall events, Environ. Sci. Technol., 44, 6305-6312, 2010.

Rozemeijer, J. C., Klein, J., Broers, H. P., Van Tol-Leenders, T. P., and Van Der Grift, B.: Water quality status and trends in agriculture-dominated headwaters; a national monitoring network for assessing the effectiveness of national and European manure legislation in The Netherlands, Environ. Monit. Assess., 186, 8981-8995, doi:10.1007/s10661-014-4059-0, 2014.

Schoch, A. L., Schilling, K. E., and Chan, K.-S.: Time-series modeling of reservoir effects on river nitrate concentrations, Adv. Water Resour., 32, 1197-1205, doi:10.1016/j.advwatres.2009.04.002, 2009.

Shrestha, R. R., Osenbrück, K., and Rode, M.: Assessment of catchment response and calibration of a hydrological model using high-frequency discharge nitrate concentration data, Hydrol. Res., 44, 995-1012, doi:10.2166/nh.2013.087, 2013. 
Simard, R. R., Beauchemin, S., and Haygarth, P. M.: Potential for preferential pathways of phosphorus transport, J. Environ. Qual., 29, 97-105, 2000.

Skeffington, R. A., Halliday, S. J., Wade, A. J., Bowes, M. J., and Loewenthal, M.: Using high-frequency water quality data to assess sampling strategies for the EU Water Framework Directive, Hydrol. Earth Syst. Sci., 19, 2491-2504, doi:10.5194/hess-192491-2015, 2015.

Stutter, M. I., Langan, S. J., and Cooper, R. J.: Spatial contributions of diffuse inputs and within-channel processes to the form of stream water phosphorus over storm events, J. Hydrol., 350, 203-214, doi:10.1016/j.jhydrol.2007.10.045, 2008.

Tiemeyer, B., Lennartz, B., and Kahle, P.: Analysing nitrate losses from an artificially drained lowland catchment (North-Eastern Germany) with a mixing model, Agr. Ecosyst. Environ., 123, 125-136, doi:10.1016/j.agee.2007.05.006, 2008.

van Boekel, E. M. P. M., Roelsma, J., Massop, H. T. L., Hendriks, R. F. A., Goedhart, P. W., and Jansen, P. C.: Nitraatconcentraties in het drainwater in zeekleigebieden: oriënterend onderzoek naar de oorzaken van de verhoogde nitraatconcentraties, Alterra-rapport 2360, Alterra Wageningen UR, Wageningen, 100 pp., 2012.

Van den Eertwegh, G. A. P. H.: Water and Nutrient budgets at field and regional scale, travel times of drainage water and nutrient loads to surface water, $\mathrm{PhD}$ thesis, Wageningen University, Wageningen, 260 pp., 2002.

van der Grift, B., Rozemeijer, J. C., Griffioen, J., and van der Velde, Y.: Iron oxidation kinetics and phosphate immobilization along the flow-path from groundwater into surface water, Hydrol. Earth Syst. Sci., 18, 4687-4702, doi:10.5194/hess-18-46872014, 2014.

Van der Salm, C., van den Toorn, A., Chardon, W. J., and Koopmans, G. F.: Water and nutrient transport on a heavy clay soil in a fluvial plain in the Netherlands, J. Environ. Qual., 41, 229-241, doi:10.2134/jeq2011.0292, 2012.

Van der Velde, Y., Torfs, P. J. J. F., van der Zee, S. E. A. T. M., and Uijlenhoet, R.: Quantifying catchment-scale mixing and its effect on time-varying travel time distributions, Water Resour. Res., 48, W06536, doi:10.1029/2011WR011310, 2012.

Van de Ven, G. P.: Man-made lowlands, history of water management and land reclamation in the Netherlands, Uitgeverij Matrijs, Utrecht, 432 pp., 2004. van Grinsven, H. J. M., ten Berge, H. F. M., Dalgaard, T., Fraters, B., Durand, P., Hart, A., Hofman, G., Jacobsen, B. H., Lalor, S. T. J., Lesschen, J. P., Osterburg, B., Richards, K. G., Techen, A. K., Vertès, F., Webb, J., and Willems, W. J.: Management, regulation and environmental impacts of nitrogen fertilization in northwestern Europe under the Nitrates Directive; a benchmark study, Biogeosciences, 9, 5143-5160, doi:10.5194/bg-9-5143-2012, 2012.

von Asmuth, J. R., Bierkens, M. F. P., and Maas, K.: Transfer function-noise modeling in continuous time using predefined impulse response functions, Water Resour. Res., 38, 23-1-23-12, doi:10.1029/2001WR001136, 2002.

Wade, A. J., Palmer-Felgate, E. J., Halliday, S. J., Skeffington, R. A., Loewenthal, M., Jarvie, H. P., Bowes, M. J., Greenway, G. M., Haswell, S. J., Bell, I. M., Joly, E., Fallatah, A., Neal, C., Williams, R. J., Gozzard, E., and Newman, J. R.: Hydrochemical processes in lowland rivers: Insights from in situ, highresolution monitoring, Hydrol. Earth Syst. Sci., 16, 4323-4342, doi:10.5194/hess-16-4323-2012, 2012.

Withers, P. J. A. and Jarvie, H. P.: Delivery and cycling of phosphorus in rivers: A review, Sci. Total Environ., 400, 379-395, 2008.

Withers, P. J. A., Ulén, B., Stamm, C., and Bechmann, M.: Incidental phosphorus losses - are they significant and can they be predicted?, J. Plant Nutr. Soil Sci., 166, 459-468, doi:10.1002/jpln.200321165, 2003.

Worrall, F., Swank, W. T., and Burt, T. P.: Changes in stream nitrate concentrations due to land management practices, ecological succession, and climate: Developing a systems approach to integrated catchment response, Water Resour. Res., 39, HWC11HWC114, 2003.

Worsfold, P. J., Gimbert, L. J., Mankasingh, U., Omaka, O. N., Hanrahan, G., Gardolinski, P. C. F. C., Haygarth, P. M., Turner, B. L., Keith-Roach, M. J., and McKelvie, I. D.: Sampling, sample treatment and quality assurance issues for the determination of phosphorus species in natural waters and soils, Talanta, 66, 273-293, 2005.

Zak, D., Kleeberg, A., and Hupfer, M.: Sulphate-mediated phosphorus mobilization in riverine sediments at increasing sulphate concentration, River Spree, NE Germany, Biogeochemistry, 80, 109-119, 2006. 